\title{
ANALISIS PENGARUH TINGKAT BAGI HASIL DEPOSITO MUDHARABAH, FDR, SUKU BUNGA, INFLASI, DAN PDB TERHADAP JUMLAH DEPOSITO MUDHARABAH PADA BANK PEMBIAYAAN RAKYAT SYARI'AH (BPRS) DI PROVINSI BANTEN
}

\author{
Shoona Kabila Mahaaba \\ Jurusan Ekonomi Syariah Fakultas Ekonomi dan Bisnis Universitas Sultan Ageng Tirtayasa \\ shoonakabila@gmail.com
}

\begin{abstract}
This research aims to analyze the variable profit-sharing rate of mudharabah deposits, FDR, inflation rates, and GDP in influencing the number of mudharabah deposits at the Sharia People Financing Bank (BPRS) in Banten Province. The data used in this study are time-series data and cross-section (panel data) for the first quarter of 2015 to the fourth quarters of 2018. Meanwhile, the independent variable used is the profit-sharing rate of mudharabah deposits, FDR, interest rates, inflation, and products Gross Domestic and the dependent variable is the number of mudharabah deposits. The method used is a quantitative method of panel data with a fixed-effect model approach. The results showed that the rate of sharing of mudharabah deposits, FDR, interest rates, inflation, and GDP had a significant effect on the number of mudharabah deposits simultaneously. But partially, the profit-sharing rate of mudharabah deposits has a positive and significant effect on the number of mudharabah deposits. FDR, interest rates, and inflation have a negative and significant effect on the number of mudharabah deposits. while GDP has a negative and not significant effect on the number of mudharabah deposits.

Keywords: Profit Sharing Rate for Mudharabah Deposits, FDR, Interest Rates, Inflation, GDP, Number of Mudharabah Deposits, Panel Data.
\end{abstract}

\section{PENDAHULUAN}

Kemunculan perbankan syariah didasari keinginan masyarakat Indonesia (mayoritas Islam) tanpa riba, hal tersebut menjadi motivasi MUI untuk merealisasikan perbankan dengan system islam. Pada tahun 1991, berdirinya bank Muamalat mendapat apresiasi tinggi dari masyarakat dan berhasil melewati masa krisis pada tahun 1998 yang menyebabkan beberapa perbankan konvensional gulung tikar. Hal tersebut memotivasi bank konvensial yang tersungkur untuk mempelajari sistem yang digunakan. Kegiatan perbankan syariah di Indonesia baru dimulai tahun 1992 seperti yang tertera pada UU No.7 tahun 1992. Dalam UU tersebut tentang perbankan sekalipun belum dapat mengatur secara tegas mengenai perbankan syariah. Pada tahun 1998, lahir UU No. 10 tahun 1998 tentang Perbankan yang secara eksplisit menetapkan bahwa bank dapat beroperasi berdasarkan prinsip-prinsip syariah. Seiring pertumbuhan perbankan syariah yang pesat di Indonesia, maka pemerintah kemudian mengeluarkan kebijakan yang khusus mengatur tentang perbankan syariah yaitu dengan menerbitkan UU No. 21 tahun 2008. Kebijakan ini memberikan kesempatan yang lebih luas untuk pengembangan jaringan perbankan syariah.

Diantaranya adalah izin pembukaan Unit Usaha Syariah (UUS) oleh bank umum konvensional atau konversi sebuah bank konvensional menjadi bank syariah. Bagi kaum muslimin, kehadiran Bank Syariah sesuai dengan kebutuhan dan tuntutan syar'i dalam pengelolaan keuangan. Namun bagi kaum lainnya (non Muslim), bank syariah merupakan sebuah alternatif lembaga jasa keuangan di samping perbankan konvensional yang telah lama ada. Semakin banyak bank di Indonesia maka akan semakin menambah daya saing antara bank, baik pada bank konvensional maupun syariah. Ini artinya, masyarakat semakin luas untuk menentukan pilihan dimana sebaiknya menyimpan dan menginvestasikan uangnya. Namun demikian populasi Muslim yang meningkat di Indonesia seharusnya menjadi peluang besar bagi bank syariah untuk meraih dana masyarakat dalam bentuk simpanan (deposito). Peluang ini diperkuat dengan lahirnya Fatwa MUI (2004) yang mengharamkan bunga bank.

Kebutuhan masyarakat akan adanya lembaga Perbankan Syariah dirasa cukup tinggi. Untuk memenuhi kebutuhan masyarakat tersebut, maka dalam sistem perbankan nasional dimungkinkan adanya pendirian Bank Syariah yang salah satu jenisnya adalah Bank Pembiayaan Rakyat Syariah (BPRS) Tersedia online : http://jurnal.stesislamicvillage.ac.id/index.php/JURNAL 
dimaksudkan untuk dapat memberikan layanan perbankan secara cepat, mudah dan sederhana kepada masyarakat khususnya pengusaha menengah, kecil dan mikro baik di pedesaan maupun perkotaan yang selama ini belum terjangkau oleh layanan Bank Umum Syariah.

Bank Pembiayaan Rakyat Syariah (BPRS) dalam menjalankan kegiatan usahanya, harus selalu memegang teguh prinsip kehati-hatian serta mampu menerapkan prinsip syariah secara konsisten, sehingga tercipta Bank Pembiayaan Rakyat Syariah yang sehat yang mampu memberikan layanan terbaik pada masyarakat. BPRS mempunyai produk yaitu penyaluran dana dan penghimpun dana. Produk penyaluran dana yaitu pembiayaan dan produk penghimpun dana yaitu giro dan tabungan, dan deposito. Penghimpun dana merupakan salah satu persoalan utama yang harus dihadapi perbankan adalah dana. Karenanya setiap perbankan syariah harus mampu menyalurkan dana agar terus dapat berkembang. Dalam hal ini harus menjaga kinerjanya agar bisa beroperasi secara optimal, bertahan dan bersaing dengan bank konvensional. Salah satu yang menjadi pertimbangan nasabah adalah kinerja keuangan bank.

Teori yang dikemukan oleh Adiwarman Karim menjelaskan tentang menjelaskan tentang dana nasabah yang dikelola oleh bank. Untuk mengetahui mekanisme deposito mudharabah terlebih dahulu mengetahui kewenangan yang diberikan pihak pemilik dana terhadap bank. Ada dua macam kewenangan yaitu, deposito mudharabah mutlaqah dan deposito mudharabah muqayaddah (Karim, 2013: 363). Muhamad mengemukakan teori tentang mekanisme deposito mudharabah, yaitu:

1. Bank bertindak sebagai pengelola dana (mudharib) dan nasabah bertindak sebagai sebagai pemilik dana (shahibul maal).

2. Pembagian keuntungan dinyatakan dalam bentuk nisbah yang telah disepakati di awal.

3. Penarikan dana oleh nasabah hanya dapat dilakukan sesuai waktu yang disepakati (Muhamad, 2014: 39).

Deposito mudharabah adalah salah satu bentuk produk pendanaan perbankan syariah. Menurut UU RI No. 21 tahun 2008 tentang perbankan syariah, adalah investasi dana berdasarkan akad mudharabah atau akad lain yang tidak bertentangan dengan prinsip syariah yang penarikannya hanya dapat dilakukan pada waktu tertentu berdasarkan akad antara nasabah penyimpan dana dan bank syariah atau Unit Usaha Syariah (UUS). Jangka waktu penarikannya ada yang 1 bulan, 3 bulan, 6 bulan, dan ada yang 12 bulan serta dapat diperpanjang otomatis.

Dengan demikian pendapatan dari deposito mudharabah tidak sebagaimana pada bunga, melainkan berfluktuasi sesuai dengan tingkat pendapatan bank syariah. Deposito mudharabah merupakan investasi nasabah kepada bank syariah, sehingga dalam akuntansinya kedudukan deposito tidak dicatat sebagai hutang bank, tetapi dicatat dan disebut sebagai investasi, biasanya disebut "investasi tidak terkait" (mudharabah muthlaqah).

Selain itu dalam menjalankan fungsi intermediasi, bank pembiayaan rakyat syariah tentu memerlukan dana untuk memenuhi kebutuhan permodalan dan memenuhi kebutuhan pembiayaan. Antara penghimpunan dana dan penyaluran dana terdapat hubungan saling ketergantungan, yaitu besar kecilnya pembiayaan yang diberikan tergantung pada besarnya atau tersedianya dana (Prasetya, Tan, \& Delis, 2015).

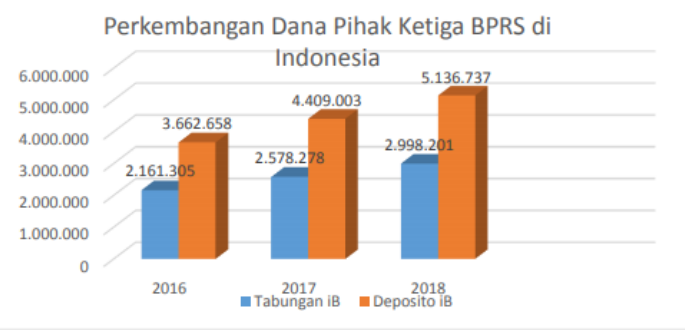

Gambar 1.1

Perkembangan Dana Pihak Kertiga BPRS Di Indonesia

Sumber: www.ojk.go.id (data diolah)

Dari Gambar 1.1 menjelaskan bahwa perkembangan dana pihak ketiga BPRS di Indonesia dari Tersedia online : http://jurnal.stesislamicvillage.ac.id/index.php/JURNAL 
tahun ke tahun terus mengalami peningkatan. Perkembangan tersebut merupakan bukti atas meningkatnya apresiasi masyarakat terhadap perbankan syariah. Hal ini membuktikan bahwa perbankan syariah telah sesuai dengan tuntutan perkembangan zaman dan menjadi sistem perbankan alternatif di Indonesia.

Selain itu dari tabel ini dapat di jelaskan bahwa deposito mudharabah penyumbang terbesar dalam dana pihak ketiga ditimbang tabungan, dimana deposito mudharabah menyumbang sebanyak $63 \%$ untuk dana pihak ketiga di BPRS di Indonesia sisanya 37\% dari tabungan.

Akan tetapi jika kita perhatikan pada provinsi Banten perkembangan deposito mudharabah BPRS di provinsi ini mengalami penurunan sebagaimana yang akan dijelaskan pada Gambar berikut ini.

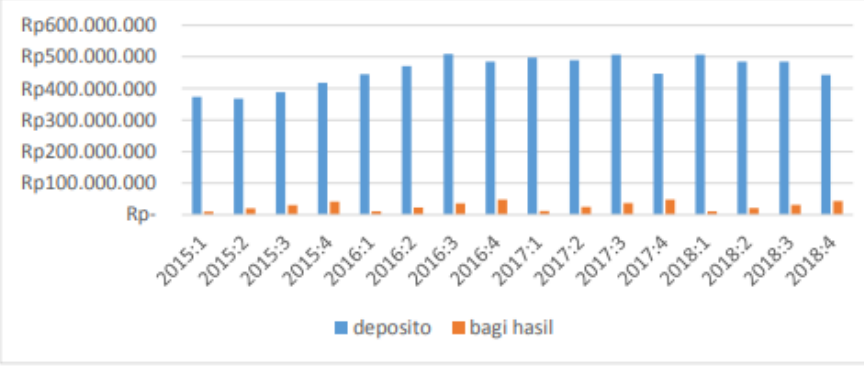

Gambar 1.2

Perkembagan Deposito Mudharabah Dan Bagi Hasil BPRS Provinsi Banten

Sumber : www.ojk.go.id (data diolah)

Berdasarkan Gambar 1.2 di atas yang menunjukan bawa perkembangan deposito mudharabah Bank Pembiayaan Rakyat Syari'ah (BPRS ) pada bulan desember 2016 sampai desember 2018 mengalami kenaikan dan penurunan pertriwulannya, yaitu pada bulan desember tahun 2016 jumlah naik sebesar Rp 484.290.390 dari bulan desember 2015 Rp 417.584.626 namun pada bulan desember 2018 mengalami penuruanan sebesar Rp 442.722.140, hal ini harus diperhatiakan oleh BPRS mengenai faktor apa saja yang membuat jumlah dana deposito mudharabah menurun. Namun jika diliat dari peningkatan jumlah bagi hasil deposito mudharabah yaitu pada bulan mei 2016 bagi hasil yang di berikan sebesar 2,59\% terus meningkat hingga dapat mencapai 10,89\% pada bulan desember 2017 dan pada bulan desember 2018 sebesar $9,86 \%$, ini menunjukan BPRS sangat mampu memberikan bagi hasil yang besar terhadap dana deposan.

Permasalahan dari penilitian ini yaitu dimana bagi hasil yang diberikan semakin besar namun perkembangan deposito mudharabah semakin menurun sebagaimana yang telah dijelaskan diatas, ini bertentangan dengan teori yaitu semakin besar tingkat bagi hasil yang berikan oleh bank maka semakin besar jumlah deposito mudharabah. Berarti dapat kita ketahui Adanya perkembangan deposito mudharabah terdapat faktor-faktor yang mempengaruhi, yaitu faktor internal dan faktor eksternal. Faktor internal tersebut berupa FDR dan bagi hasil yang diberikan oleh BPRS yang terdapat di Provinsi Banten, selain itu faktor eksternal yang mempengaruhi deposito mudharabah berupa suku bunga, inflasi dan PDB.

Terdapat research gap antara hasil penelitian yang satu dengan hasil penelitian lainnya yang menunjukkan adanya ketidakkonsistenan mengenai pengaruh tingkat bagi hasil deposito mudharabah, FDR, suku bunga, inflasi, dan PDB terhadap jumlah deposito mudharabah. Untuk Faktor internal yang berpengaruh terhadap pendanaan perbankan khususnya perbankan syariah yaitu bagi hasil yang diterima nasabah. Tinggi rendahnya bagi hasil yang ditawarkan bank kepada nasabah akan sangat menentukan minat nasabah untuk menyimpan uangnya pada bank tersebut (Rivai, V., dan Arifin, 2010 : 50).

Hassan dan Kasim (2012) menyebutkan bagi hasil berpengaruh positif terhadap deposito mudharabah. Hasil yang sama ditunjukkan oleh Aulia, Agung dan Sri (2013), dimana bagi hasil berpengaruh positif terhadap deposito mudharabah. Namun Novianto dan Hadiwidjojo (2013) menemukan bagi hasil berpengaruh negatif terhadap terhadap deposito mudharabah. Anisah dkk (2013) menemukan hasil yang sama yaitu bagi hasil berpengaruh negatif terhadap terhadap deposito mudharabah.

Financing To Deposit Ratio (FDR) berdasarkan pada hasil penelitian oleh Nur, Anisah dkk (2013), telah membuktikan bahwa FDR mempunyai pengaruh negatif terhadap pertumbuhan deposito

Tersedia online : http://jurnal.stesislamicvillage.ac.id/index.php/JURNAL 
mudharabah. Hasil yang sama ditunjukkan oleh Piliyanti dan Wahyuni (2014), menyebutkan FDR berpengaruh negatif terhadap deposito mudharabah. Namun berbeda dengan penelitian Ruslizar dan Rahmawaty (2016), menemukan FDR berpengaruh positif terhadap deposito mudharabah.

Suku Bunga dari hasil penelitian Ana (2010), melakukan penelitian hasilnya bahwa suku bunga berpengaruh secara positif terhadap deposito mudharabah. Namun berbeda dengan Aulia, Agung dan Sri (2013), membuktikan bahwa suku bunga mempunyai pengaruh negatif terhadap pertumbuhan deposito mudharabah. Hasil yang sama ditunjukkan oleh Lestari dan Trikunawangsih (2014), menyebutkan suku bunga mempunyai pengaruh negatif terhadap pertumbuhan deposito mudharabah.

Inflasi pada penelitian Ali, Hassan dan Kasim (2012), menyebutkan inflasi berpengaruh negatif terhadap deposito mudharabah. Hasil yang sama ditunjukkan oleh Novianto dan Hadiwidjojo (2013), membuktikan inflasi berpengaruh negatif terhadap deposito mudharabah. Namun Lestari dan Trikunawangsih (2014) menyebutkan inflasi berpengaruh positif terhadap deposito mudharabah.

Produk Domestik Bruto (PDB) berdasarkan hasil penelitian Novianto dan Hadiwidjojo (2013), menyebutkan PDB berpengaruh negatif terhadap deposito mudharabah. Namun Rudiansyah (2014) menyebutkan PDB berpengaruh positif terhadap deposito mudharabah. Hasil yang sama ditunjukan Hilman (2016), menyebutkan PDB berpengaruh positif terhadap deposito mudharabah.

Berarti dapat kita ketahui Adanya perkembangan jumlah deposito mudharabah terdapat faktorfaktor yang mempengaruhi, yaitu faktor internal dan faktor eksternal. Faktor internal tersebut berupa FDR dan bagi hasil yang diberikan oleh BPRS yang terdapat di Provinsi Banten, selain itu faktor eksternal yang mempengaruhi deposito mudharabah berupa suku bunga, inflasi dan PDB.

Faktor pertama yang mempengaruhi deposito mudharabah adalah jumlah bagi hasil. Tujuan masyarakat berinvestasi adalah untuk mendapatkan keuntungan dan tidak dipungkiri bahwa faktor penentu masyarakat menginvestasikan dananya di bank selain bersifat liquid juga untuk mendapatkan keuntungan yang maksimal. Dan bagi hasil di bank sendiri tidak terpengaruh oleh tingkat suku bunga yang ditetapkan Bank Indonesia sehingga bank syariah bisa menetukan sendiri besaran bagi hasil yang akan diberikan kepada nasabah (Rivai, V., dan Arifin, 2010: 56).

Faktor kedua yang mempengaruhi deposito mudharabah adalah Financing Deposit To Ratio (FDR). Dimana antara jumlah kredit yang diberikan bank dan diterima oleh bank. FDR ditentukan oleh perbandingan antara jumlah perbandingan dan jumlah perbandingan yang diberikan oleh dana masyarakat yang dihimpun yaitu mencakup giro, simpanan berjangka (deposito) dan tabungan. Rasio ini menunjukkan seberapa besar kemampuan bank dalam membayar kembali penarikan dana yang dilakukan deposan dengan mengandalkan kredit yang diberikan sebagai sumber likuiditas. Semakin tinggi rasio ini, maka semakin rendah pula kemampuan likuiditas bank tersebut jika ada deposan menarik dananya sehingga kemungkinan suatu bank dalam kondisi bermasalah semakin besar(Antonio, 2009: 55).

Faktor ketiga yang mempengaruhi deposito mudharabah adalah suku bunga. Tingkat suku bunga merupakan salah satu faktor ekonomi makro yang mempengaruhi jumlah deposito mudharabah pada bank syariah. Sejauh ini ketertarikan masyarakat dalam mendepositokan dananya dipengaruhi oleh keinginannya untuk mendapatkan keuntungan yang lebih besar, dalam arti suku bunga yang lebih besar pada bank konvensional atau bagi hasil yang lebih tinggi pada bank syariah. Tingkat bunga dapat dipandang sebagai pendapatan yang diperoleh dari tabungan. Makin tinggi tingkat suku bunga, maka makin tinggi pula keinginan masyarakat/nasabah untuk menabung. Begitu pula sebaliknya, makin rendah tingkat suku bunga, makin rendah pula keinginan masyarakat/nasabah untuk menabung. Hal ini menunjukkan bahwa tingkat suku bunga yang lebih tinggi akan lebih disukai oleh masyarakat. Dengan adanya suku bunga yang lebih tinggi, masyarakat akan lebih terdorong untuk mengorbankan/mengurangi pengeluaran mereka untuk konsumsi, dan memilih untuk menyimpan uang mereka di bank (Irham, 2011: 80).

Faktor keempat yang mempengaruhi deposito mudharabah adalah inflasi. Inflasi merupakan kondisi dimana ekonomi mengalami ketidak stabilan karena meningkatnya harga-harga yang menjadi tidak stabil yang secara terus-menerus dengan waktu yang tidak dapat diperkirakan dan itu mengakibatkan masyarakat lebih memilih menggunakan dananya untuk kebutuhan konsumsi dibandingkan untuk digunakan pada hal lain. Karena inflasi membuat masyarakat tidak memiliki dana lebih untuk disimpan

Tersedia online : http://jurnal.stesislamicvillage.ac.id/index.php/JURNAL 
dan diinvestasikan. Oleh sebab itu, sangatlah penting pengendalian inflasi, karena inflasi yang tinggi akan memberikan dampak yang negatif kepada kehidupan masyarakat (Diyanto \& Savitri, 2015: 50).

Faktor kelima yang mempengaruhi deposito mudharabah adalah Produk Domestik Bruto (PDB). Variabel PDB digunakan untuk mewakili besarnya pendapatan atau kegiatan ekonomi. Kenaikan nilai PDB menunjukkan naiknya jumlah output yang diproduksi oleh suatu perekonomian. Pertumbuhan PDB tersebut juga mencerminkan naiknya pendapatan yang diterima oleh faktor-faktor produksi yang digunakan diperekonomian tersebut. Dalam kaitan antara pendapatan, konsumsi, dan tabungan diketahui bahwa tidak semua pendapatan yang diterima akan digunakan untuk konsumsi, melainkan sebagian akan disimpan. Jadi, tabungan adalah bagian pendapatan yang tidak dikonsumsi dalam periode tertentu. Suatu kenaikan dalam pendapatan akan meningkatkan konsumsi dan tabungan. Dengan demikian terdapat hubungan positif antara pendapatan dan simpanan (Sukirno, 2015: 140).

Penelitian ini memiliki kelebihan dibandingkan dengan penelitian lainnya mulai dari variabel, objek penelitian lebih banyak dan data yang diambil dalam kurun waktu yang berbeda. Dengan menggunakan data yang terbaru sehingga hasil yang didapat akan lebih menggambarkan situasi Bank Pembiayaan Rakyat Syariah pada saat ini.

Berdasarkan pada fenomena tersebut, maka diperlukan suatu kajian yang mendalam. Maka penulis mencoba menelitinya dengan sebuah proposal yang berjudul "Analisis Pengaruh Tingkat Bagi Hasil Deposito Mudharabah, FDR, Suku Bunga, Inflasi, dan PDB terhadap Jumlah Deposito Mudharabah pada Bank Pembiayaan Rakyat Syari'ah (BPRS) di Provinsi Banten ”

\section{TINJAUAN LITERATUR}

\section{Bank Pembiayaan Rakyat Syariah (BPRS)}

Undang-Undang (UU) Nomor 21 Tahun 2008 Tentang Bank Syariah telah mengatur secara khusus eksistensi bank syariah di Indonesia. UndangUndang tersebut melengkapi dan menyempurnakan UU No. 7 Tahun 1992 Tentang Perbankan sebagaimana telah diubah dengan UU No. 10 Tahun 1998 yang belum spesifik sehingga perlu diatur khusus dalam Undang-Undang tersendiri. Menurut pasal 18 UUNo. 21 Tahun 2008, Bank Syariah terdiri atas Bank Umum Syariah dan Bank Pembiayaan Rakyat Syariah. Sedangkan pasal 1 UU No. 21 Tahun 2008 tentang Ketentuan Umum disebutkan pengertian dari Bank Pembiayaan Rakyat Syariah (BPRS) adalah Bank Syariah yang dalam kegiatanya tidak memberikan jasa dalam lalu lintas pembayaran (Ifham, 2010).

\section{Deposito Mudharabah}

Deposito, menurut UU No. 21 tahun 2008 adalah investasi dana berdasarkan akad mudharabah atau akad yang lain yang tidak bertentangan dengan prinsip syariah yang penarikannya hanya dapat dilakukan pada waktu tertentu berdasarkan akad antara nasabah penyimpan dan bank syariah atau UUS. Deposito merupakan dana yang dapat diambil sesuai dengan perjanjian berdasarkan jangka waktu yang telah disepakati. Deposito mudharabah merupakan dana investasi yang ditempatkan oleh nasabah yang tidak bertentangan dengan prinsip syariah dan penarikannya hanya dapat dilakukan pada waktu tertentu, misalnya deposito jangka waktu satu bulan, maka dapat dicairkan setelah satu bulan (Ismail, 2011:91).

Deposito berjangka diterbitkan atas nama, baik atas nama perorangan maupun atas nama badan hukum. Bukti kepemilikan deposito berjangka yang diberikan oleh bank kepada pemegang rekening deposito berjangka berupa bilyet deposito. Didalam bilyet deposito tertera nama pemiliknya, yang merupakan pemegang hak atas deposito berjangka, yaitu nama perorangan ataupun badan hukum. Pihak yang dapat mencairkan deposito berjangka hanya pihak yang namanya tercantum didalam bilyet deposito berjangka (Nurianto, 2010: 35). Jangka waktu deposito berjangka ini berbeda-beda, mulai dari deposito jangka waktu 1 bulan, deposito jangka waktu 3 bulan, deposito jangka waktu 6 bulan, deposito jangka waktu 12 bulan, dan deposito jangka waktu 24 bulan.

Tersedia online : http://jurnal.stesislamicvillage.ac.id/index.php/JURNAL 


\section{Landasan Syariah}

1. Al-Qur'an

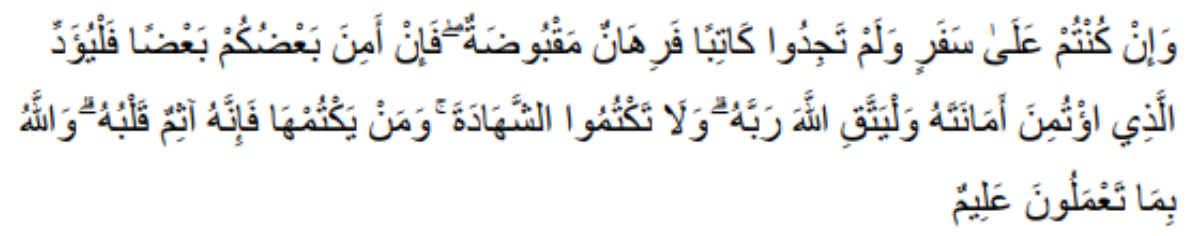

Artinya : "Akan tetapi jika sebagian kamu mempercayai sebagian yang lain, maka hendaklah yang dipercayai itu menunaikan amanatnya (hutangnya) dan hendaklah ia bertakwa kepada Allah Tuhannya; dan janganlah kamu (para saksi) menyembunyikan persaksian. Dan barangsiapa yang menyembunyikannya, maka sesungguhnya ia adalah orang yang berdosa hatinya; dan Allah Maha Mengetahui apa yang kamu kerjakan." (Q.S. Al-Baqarah : 283)

Maksud Ayat diatas adalah jika seseorang menitipkan sesuatu kepada orang lain sebagai amanat, dan ia dipercayakan untuk itu, maka orang yang diamanatkan harus menyerahkannya saat diminta. Dan hendaknya ia takut kepada Allah yang memelihara dan mengawasinya, sehingga nikmat-Nya di dunia dan akhirat tidak diputus. Janganlah menyembunyikan keterangan atau persaksian ketika diminta. Dan barangsiapa menyembunyikannya, maka ia adalah orang yang berdosa dan buruk hati. Allah Maha Mengetahui segala apa yang kalian lakukan. Dan Dia akan memberi balasan sesuai hak kalian.

\section{Konsep Bagi Hasil}

\section{Tingkat Bagi Hasil}

Menurut Sutan tingkat bagi hasil (rate of return) adalah tingkat pengembalian bersih atas modal/investasi atau dana yang disimpan di perbankan. Dalam perbankan syariah, tingkat bagi hasil (rate of return) bergantung pada besar kecilnya nisbah yang diberikan dan laba yang diperoleh oleh bank (Sutan, 2014:31).

Tingkat bagi hasil (rate of return) dapat diketahui melalui laporan distribusi bagi hasil pada laporan keuangan yang diterbitkan oleh bank umum syariah. Adapun cara menghitung rate of return adalah : ( Sutan , $2014: 33$ )

$\mathrm{ROR}=$ tingkat bagi hasil (rate of return)

$\mathrm{BBH}=$ bonus dan bagi hasil

SSRH $=$ saldo rata-rata harian dana pihak ketiga

Faktor-Faktor Yang Mempengaruhi Bagi Hasil

Menurut Ismail ada beberapa faktor yang mempengaruhi bagi hasil yang akan diberikan pada setiap akad yaitu : ( Ismail, 2011:95 ).

a. Investment Rate

Merupakan presentase dana yang di investasikan kembali oleh bank syariah baik ke dalam pembiayaan maupun penyaluran dan lainnya. Kebijakan ini di ambil karena adanya ketentuan dari bank indonesia, bahwa sejumlah presentase tertentu atas dana yang dihimpun dari masyarakat, tidak boleh diinvestasikan, akan tetapi harus ditempatkan dalam giro wajib minimun untuk menjaga liquiditas bank syariah.

b. Total dana investasi

Total dana investasi yang diterima oleh bank syariah kan mempengaruhi bagi hasil yang diterima oleh nasabah investor. Total dana yang berasal dari investasi mudharabah dapat dihitung menggunakan saldo minimal bulanan atau saldo harian. Saldo minimal bulanan merupakan saldo minimal yang pernah mengendap dalam satu bulan. Saldo minimal akan digunakan sebagai dasar perhitungan bagi hasil. Saldo harian merupakan saldo rata-rata pengendapan yang dihitung secara harian, kemudian nominal saldo harian digunakan sebagai dasar perhitungan bagi hasil.

Tersedia online : http://jurnal.stesislamicvillage.ac.id/index.php/JURNAL 
c. Jenis dana

Investasi mudharabah dalam penghimpunan dana, dapat ditawarkan dalam beberapa jenis yaitu; tabungan mudharabah, deposito mudharabah, dan sertifikat investasi mudharabah antar bank syariah (SIMA). Setiap jenis dana investasi memiliki karakteristik yang berbeda-beda sehingga akan berpengaruh pada besarnya bagi hasil.

\section{d. Nisbah}

Nisbah merupakan presentase tertentu yang disebutkan dalam akad kerja sama usaha (mudharabah dan musyarakah) yang telah disepakati antara bank dan nasabah investor. Karakteristik nisbah akan berbedabeda dilihat dari bebrapa segi antara lain:

1) Presentase nisbah antar bank syariah akan berbeda, hal ini tergantung pada kebijakan masingmasing bank syariah.

2) Presentase nisbah akan berbeda sesuai dengan jenis dana yang dihimpun. Misalnya, nisbah antara tabungan dan deposito akan berbeda.

3) Jangka waktu investasi mudharabah akan berpengaruh pada besarnya presentase nisbah bagi hasil.

e. Kebijakan Akuntansi

Kebijakan akuntansi akan berpengaruh pada besarnya bagi hasil. Beberapa kebijakan akuntansi yang akan mempengaruhi bagi hasil antara lain penyusutan. Penyusutan akan berpengaruh pada laba usaha bank. Bila bagi hasil menggunakan metode profit/loss sharing, maka penyusutan akan berpengaruh pada bagi hasil, akan tetapi bila menggunakan revenue sharing, maka penyusutan tidak akan memengaruhi bagi hasil.

\section{Financing to Deposit Ratio (FDR)}

Agung (2014) menyebut Financing to Deposit Ratio (FDR) adalah kemampuan bank dalam menyediakan dana dan menyalurkan dana kepada nasabah. Nilai FDR menunjukkan efektif tidaknya suatu bank dalam menyalurkan pembiayaan, apabila nilai FDR menunjukkan persentase terlalu tinggi maupun terlalu rendah maka bank dinilai tidak efektif dalam menghimpun dana dan menyalurkan dana yang diperoleh dari nasabah, sehingga akan mempengaruhi laba yang didapatkan oleh bank.

Menurut Rivai dan Arifin Financing To Deposit Ratio adalah rasio yang menggambarkan tingkat kemampuan bank syariah dalam mengembalikan dana nasabah sebagai pihak ketiga melalui pendapatan yang diperoleh dari pembiayaan mudharabah (Rivai, V., dan Arifin, 2010). FDR sebenarnya adalah Loan To Deposit Ratio (LDR) dalam bank konvensional, perbedaan penyebutan ini dikarenakan dalam bank syariah tidak mengenal istilah loan (pinjaman) melainkan hanya dikenal dengan sebutan financing (pembiayaan). Suatu bank akan dikatakan likuid apabila bank mampu memenuhi semua liabilitas (kewajiban) baik dalam jangka pendek maupun jangka panjang, selain dari pada itu bank yang dikatakan likuid juga diharapkan mampu memenuhi permintaan atas dana yang diajukan nasabah tanpa adanya penangguhan dalam pemberian dana melalui pembiayaan tersebut (Surya, et al., 2016: 6).

FDR dapat digunakan sebagai indikator untuk mengukur kemampuan bank syariah dalam menjalankan salah satu fungsinya sebagai lembaga intermediasi yang baik artinya semakin stabil angka FDR yang dimiliki bank syariah maka semakin baik pula bank syariah tersebut dalam menjalankan fungsinya sebagai lembaga intermediasi. Jadi kesimpulannya apabila terjadi penurunan yang drastis dalam angka FDR tersebut maka akan membawa dampak kepada angka pembiayaan yang disalurkan oleh bank syariah, sehingga FDR berpengaruh positif terhadap pembiayaan akad mudharabah. Adapun rumus untuk melihat rasio Financing To Deposit Ratio, adalah sebagai berikut: (Rivai, V., dan Arifin, 2010)

Dan dalam penilaian Financing To Deposit Ratio (FDR) juga memiliki kriteria atau persentase penilaian peringkat kesehatan, sebagai berikut:

Tersedia online : http://jurnal.stesislamicvillage.ac.id/index.php/JURNAL 
Tabel 2.1

Kriteria Penilaian Tingkat Kesehatan Bank Dengan FDR

\begin{tabular}{|l|l|l|}
\hline Peringkat & Nilai & Keterangan \\
\hline Peringkat komposit 1 & $50 \%<$ FDR & Sangat sehat \\
\hline Peringkat komposit 2 & $75 \%<$ FDR & Sehat \\
\hline Peringkat komposit 3 & $80 \%<$ FDR & Cukup sehat \\
\hline Peringkat komposit 4 & $100 \%<$ FDR & Kurang sehat \\
\hline Peringkat komposit 5 & FDR $>120 \%$ & Tidak sehat \\
\hline
\end{tabular}

Sumber : Surat Edaran Bank Indonesia No. 6/23/DPNP 2004

\section{Suku Bunga BI}

Menurut Kasmir, bunga juga dapat diartikan sebagai harga yang harus dibayar kepada nasabah (yang memiliki simpanan) dengan yang harus dibayar oleh nasabah kepada bank (nasabah yang memperoleh pinjaman). Sedangkan suku bunga adalah rasio dari bunga terhadap jumlah pinjaman. (Kasmir, $2012: 121$ )

Menurut Robert, BI rate merupakan indikasi suku bunga jangka pendek yang diinginkan Bank Indonesia dalam upaya mencapai target inflasi. BI rate digunakan sebagai acuan dalam operasi moneter untuk mengarahkan agar suku bunga (Robert, 2011: 97). Selanjutnya suku bunga BI diharapkan mempengaruhi PUAB, suku bunga pinjaman, dan suku bunga lainnya dalam jangka panjang Menurut Bank Indonesia BI rate adalah suku bunga kebijakan yang mencerminkan sikap atau stance kebijakan moneter yang ditetapkan oleh Bank Indonesia dan diumumkan kepada publik.

BI rate diumumkan oleh Dewan Gubernur Bank Indonesia setiap Rapat Dewan Gubernur bulanan dan diimplementasikan pada operasi moneter yang dilakukan Bank Indonesia melalui pengelolaan likuiditas (liquidity management) di pasar uang untuk mencapai sasaran operasional kebijakan moneter

\section{Inflasi}

Hasim menyebutkan Inflasi adalah gejala ekonomi yang menunjukkan naik tingkat harga secara umum yang berkesinambungan. Syarat inflasi yanitu terjadi kenaikan harga secara umum dan terus menerus. Jika satu dua jenis barang saja yang naik, itu bukan merupakan inflas, kenaikan harga yang bersifat sementara, umpamanya kenaikan harga karen amusiman, menjelang hari raya, bencana, dan sebgainya, tidak disebut inflasi (Hasyim, 2016: 186).

\section{Produk Domestik Bruto (PDB)}

Menurut Tabrizi menyebutkan Domestik Bruto (PDB) Produk Domestik Bruto adalah jumlah semua barang dan jasa yang dihasilkan oleh sesuatu negara dalam periode tertentu. Komponen yang ada dalam PDB yaitu pendapatan, investasi, pengeluaran pemerintah dan selisih ekspor impor. Produk Domestik Bruto merupakan salah satu indikator penting untuk mengatasi kondisi ekonomi di suatu negara dalam suatu periode tertentu, baik atas dasar harga berlaku maupun atas dasar harga konstan (Tabrizi, 2014: 28).

Produk Domestik Bruto (PDB) menghitung hasil produksi suatu perekonomian tanpa memperhatikan siapa pemilik faktor produksi tersebut. Semua faktor produksi yang berlokasi dalam perekonomian tersebut output-nya diperhitungkan dalam PDB. Akibatnya, PDB kurang memberikan gambaran tentang berapa sebenarnya output yang dihasilkan oleh faktor-faktor produksi milik perekonomian domestik (Jimmi, 2014: 98).

Produk Domsetik Bruto memang tidak bisa dikatakan mengambarkan output yang dihasilkan oleh faktor-faktor sebenarnya, tapi Produk Domestik Bruto (PDB) lebih sering digunakan sebagai acuan terhadap keadaan suatu perekonomian. counting atau penghitungan ganda, yaitu menghitung suatu produk

Tersedia online : http://jurnal.stesislamicvillage.ac.id/index.php/JURNAL 
(Jimmi, 2014 : 98).

\section{Kerangka Pemikiran}

Berdasarkan teori-teori yang telah dideskripsikan tersebut, selanjutnya dianalisis secara kritis dan sistematis, sehingga menghasilkan sintesa tentang hubungan antar variabel yang diteliti. Sintesa tentang hubungan variabel tersebut, selanjutnya digunakan untuk merumuskan hipotesis kerangka pemikiran dalam penelitian ini dapat digambarkan sebagai berikut:

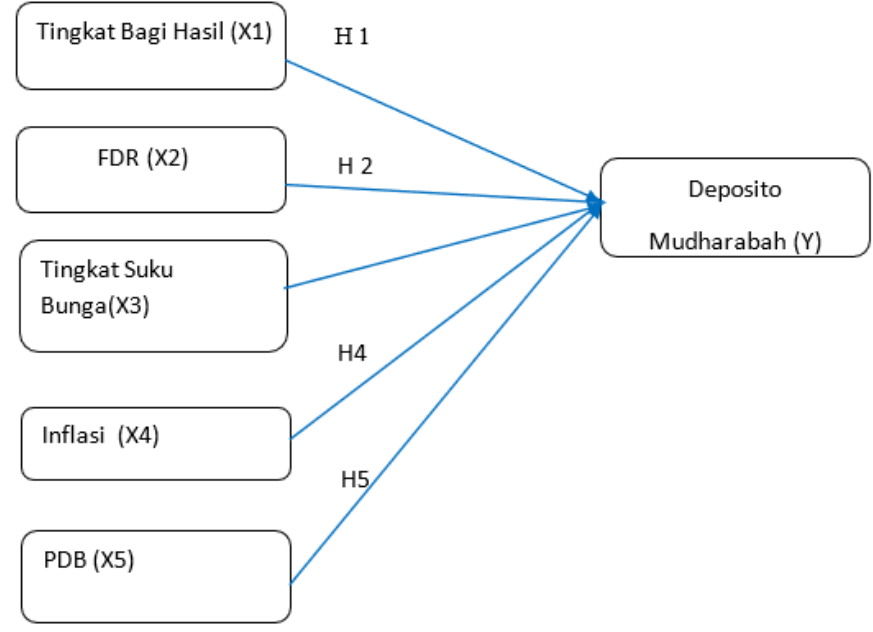

Gambar 2.1

Kerangka Pemikiran

Sumber: Hasil penelitian Ruslizar dan Rahmawaty(2016), Hilman (2016), Meutia(2017), Baehaqie dkk (2017),

Sholikha(2018), Rahayu dkk (2018).

\section{METODE PENELITIAN}

Dalam penelitian ini, penulis menggunakan jenis penelitian kuantitatif, karena penelitian ini berlandaskan pada filsafat positivisme, digunakan untuk meneliti pada populasi atau sampel tertentu, metode penelitian kuantitatif adalah metode penelitian yang berdasarkan pada filsafat positifisme digunakan untuk meneliti pada populasi atau sampel tertentu, teknik pengambilan sampel pada umumnya digunakan secara random, pengumpulam data menggunakan instrumen penelitian, analisis data bersifat statistik dengan tujuan untuk menguji hipotesis yang telah ditetapkan. Penelitian ini menggunakan angkaangka yang di jumlahkan sebagai data yang kemudian di analisis (Uhar, 2014: 49).

Metode ini dimaksud untuk menjelaskan fenomena dengan menggunakan data-data numerik, kemudian dianalisis yang umunya menggunakan statistik. Pendekatan kuantitatif memusatkan perhatian pada gejala-gejala yang mempunyai kerekteristik tertentu di dalam kehidupan (Uhar, 2014 : 50)

Jika dilihat dari segi pengungkapan variabel, penelitian ini termasuk dalam jenis penelitian korelasional (correlational research) yang merupakan tipe penelitian dengan karakteristik masalah berupa hubungan korelasional antara dua variabel atau lebih.

\section{Analisis Statistik Deskriptif}

\section{HASIL PENELITIAN DAN PEMBAHASAN}

1 Deposito Mudharabah

Deposito Mudharabah adalah penyumbang pada dana pihak ketiga yang sangat berpengaruh kepada stabilitas keuangan pada BPRS sehingga dapat mempertahankan bank tersebut. Berikut adalah perkembangan Deposito Mudharabah pada masing-masing bank pembiayaan rakyat syariah periode 2015-2018 :

Tersedia online : http://jurnal.stesislamicvillage.ac.id/index.php/JURNAL 


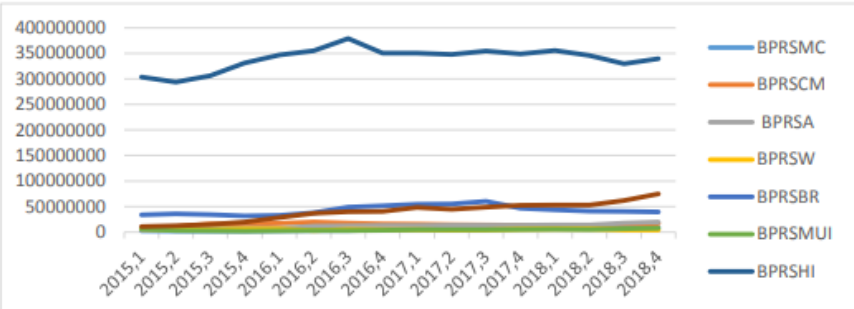

Gambar 4.1

Perkembangan Deposito Mudharabah Bank Pembiayaan Rakyat Syariah di Banten Periode 2015-2018

Sumber : Laporan Keuangan Masing-masing BPRS (Data Diolah)

Berdasarkan pada gambar dan gambar 4.1 tersebut menunjukan bahwa pada tahun 2015 jumlah deposito mudharabah tertinggi pada BPRS Mulia Harta Insan Karimah yaitu sebesar Rp 303.810.177 dan sekaligus deposito mudharabah tertinggi dalam kurung waktu 4 tahun terakhir dan disusul oleh BPRS Mulia Berkah Abadi yaitu sebesar Rp 11039067.

Pada Triwulan I tahun 2016 BPRS Cilegon Mandiri mengalami penurunan yang sangat signifikan dari Rp 17.113.350 menjadi Rp 11648500 pada triwulan I tahun 2018, pada tahun yang sama BPRS Wakalumi mengalami penurunan dari Rp 6.423.005 pada triwulan I tahun 2016 menjadi Rp 5.981.546 pada triwulan I tahun 2018. Keadaan Jumlah Deposito Mudharabah Bank Pembiayan Rakyat Syariah di Provinsi Banten selama 4 tahun terakhir mangalami keadaan yang fluktuatif dengan nilai rata-rata sebesar Rp 57,974,399

\section{Bagi Hasil}

Tingkat Bagi Hasil (rate of return) adalah tingkat pengembalian bersih atas modal/investasi atau dana yang disimpan di perbankan. Dalam perbankan syariah, tingkat bagi hasil (rate of return) bergantung pada besar kecilnya nisbah yang diberikan dan laba yang diperoleh oleh bank ( Sutan, 2014 :31 ). Berikut adalah perkembangan bagi hasil pada masing-masing Bank Pembiayaan Rakyat syariah periode 2015-2018 yang menjadi sampel penelitian :

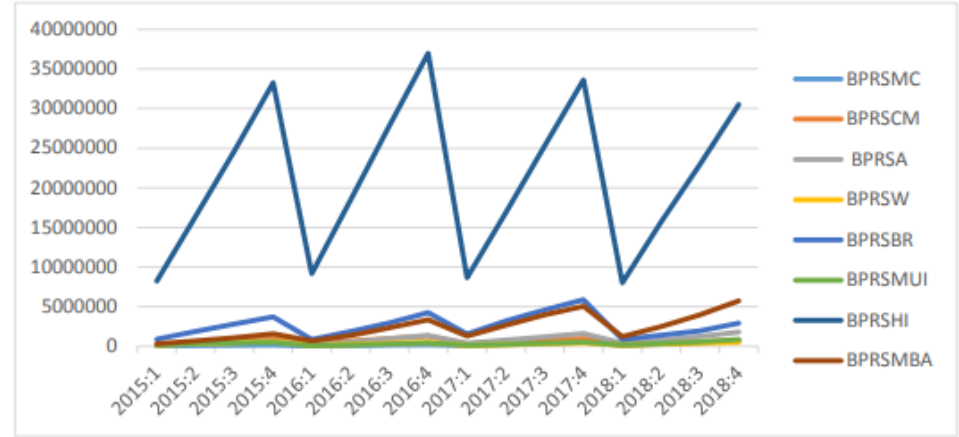

Gambar 4.2

Perkembangan Bagi Hasil Bank Pembiayaan Rakyat syariah di Banten Periode 2015-2018 Sumber: Laporan Keuangan Masing-masing BPRS (Data Diolah)

Bagi hasi deposito mudharabah terendah terjadi di triwulan I tahun 2016 pada BPRS Muamalah Cilegon sebesar Rp 42.773. Sedangkan bagi hasi deposito mudharabah terjadi di triwulan IV tahun 2016 Rp 37.002.256 pada BPRS Mulia Harta Insan Karimah yang memberikan tingkat bagi hasil tertinggi dari semua BPRS selama 4 tahun terakhir. Terlihat pada gambar 4.2 bagi hasil yang di berikan BPRS selama 4 mengalami fluktiatif dengan nilai rata - rata sebesar Rp 3,540,056

3 FDR

Financing to deposit ratio adalah rasio yang menggambarkan tingkat kemampuan bank syariah

Tersedia online : http://jurnal.stesislamicvillage.ac.id/index.php/JURNAL 
dalam mengembalikan dana nasabah sebagai pihak ketiga melalui pendapatan yang diperoleh dari pembiayaan mudharabah (Rivai, V., dan Arifin, 2010).

Suatu bank akan dikatakan likuid apabila bank mampu memenuhi semua liabilitas (kewajiban) baik dalam jangka pendek maupun jangka panjang, selain dari pada itu bank yang dikatakan likuid juga diharapkan mampu memenuhi permintaan atas dana yang diajukan nasabah tanpa adanya penangguhan dalam pemberian dana melalui pembiayaan tersebut (Surya et al., 2016: 6).

Rasio ini menunjukkan salah satu penilaian likuiditas bank. Menurut Surat Edaran BI No. 3/30 DPNP tanggal 14 Desember 2001, FDR diukur dari perbandingan antara jumlah kredit yang diberikan terhadap jumlah da na pihak ketiga.

Berikut adalah perkembangan FDR pada masing-masing Bank Pembiayaan Rakyat syariah periode 2015-2018 yang menjadi sampel penelitian :

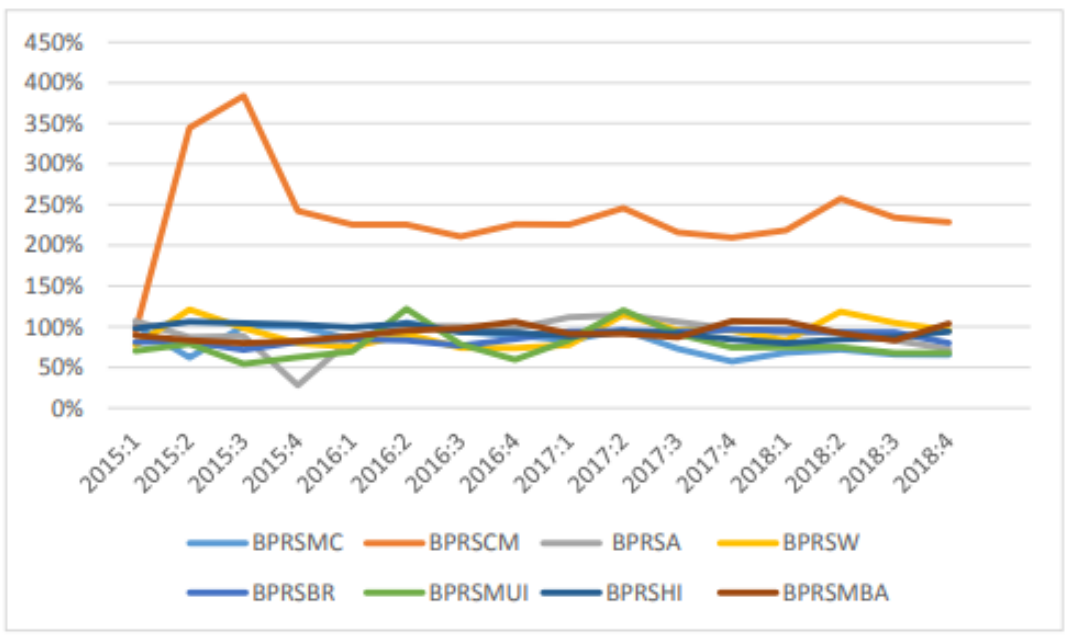

Gambar 4.3

Perkembangan FDR Pembiayaan Rakyat syariah di Banten Periode 2015-2018 Sumber : Laporan Keuangan Masing-masing BPRS (Data Diolah)

FDR terendah terjadi di triwulan II tahun 2015 pada BPRS Muamalah Cilegon sebesar 62\% Sedangkan FDR tertinggi terjadi di triwulan III tahun 2015 384\% pada BPRS Cilegon Mandiri yang mengalami FDR tertinggi dari semua BPRS selama 4 tahun terakhir. Terlihat pada gambar 4.3 bagi hasil yang di berikan BPRS selama 4 mengalami fluktiatif dengan nilai rata - rata sebesar $107 \%$

\section{Tingkat Suku Bunga}

Menurut Kasmir, bunga juga dapat diartikan sebagai harga yang harus dibayar kepada nasabah (yang memiliki simpanan) dengan yang harus dibayar oleh nasabah kepada bank (nasabah yang memperoleh pinjaman). Sedangkan suku bunga adalah rasio dari bunga terhadap jumlah pinjaman. (Kasmir, $2012: 121$ ). BI rate digunakan sebagai acuan dalam operasi moneter untuk mengarahkan agar suku bunga ( Robert, 2011 : 97 ).

Berikut adalah perkembangan suku bunga periode 2015-2018 yang menjadi sampel penelitian:

Tersedia online : http://jurnal.stesislamicvillage.ac.id/index.php/JURNAL 


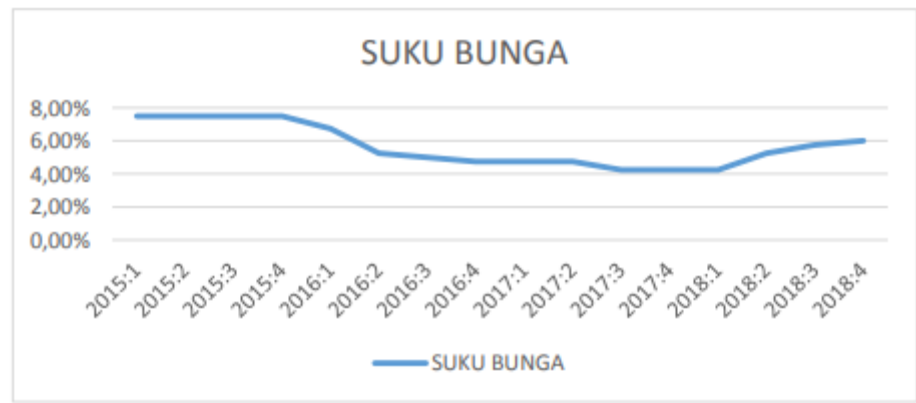

Gambar 4.4

Perkembangan Suku Bunga Periode 2015-2018

Sumber : Laporan Keuangan Masing-masing BPRS (Data Diolah)

Suku bunga terendah terjadi di triwulan I tahun 2018 sebesar 4,25\%, Sedangkan suku bunga tertinggi terjadi di triwulan I tahun 2015 sebesar $7.50 \%$ pada provinsi banten selama 4 tahun terakhir. Terlihat pada gambar 4.4 suku bunga selama 4 mengalami fluktiatif dengan nilai rata - rata sebesar $5,69 \%$.

5 Inlfasi

Inflasi adalah gejala ekonomi yang menunjukkan naik tingkat harga secara umum yang berkesinambungan. Syarat inflasi yanitu terjadi kenaikan harga secara umum dan terus menerus. Jika satu dua jenis barang saja yang naik, itu bukan merupakan inflas, kenaikan harga yang bersifat sementara, umpamanya kenaikan harga karen amusiman, menjelang hari raya, bencana, dan sebagainya, tidak disebut inflasi ( Hasyim, 2016 : 186).

Berikut adalah perkembangan inflasi periode 2015-2018 yang menjadi sampel penelitian:

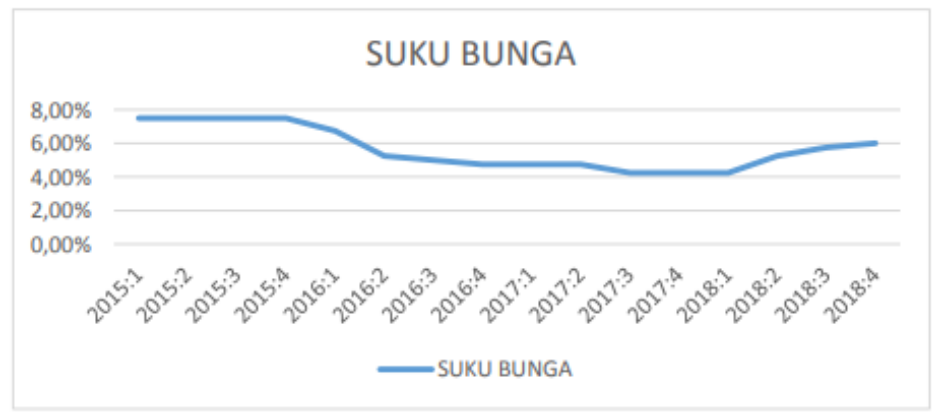

Gambar 4.5

Perkembangan Inflasi di Banten Periode 2015-2018

Sumber : Laporan Keuangan Masing-masing BPRS (Data Diolah)

Inflasi terendah terjadi di triwulan I tahun 2017 sebesar 0.08\%, Sedangkan Inflasi tertinggi terjadi di triwulan IV tahun 2015 sebesar $0.99 \%$ pada Provinsi Banten selama 4 tahun terakhir. Terlihat pada gambar 4.5 Inflasi selama 4 mengalami fluktiatif dengan nilai rata - rata sebesar $0.45 \%$.

\section{Produk Domestik Bruto (PDB)}

Produk Domestik Bruto adalah jumlah semua barang dan jasa yang dihasilkan oleh sesuatu negara dalam periode tertentu. Komponen yang ada dalam PDB yaitu pendapatan, investasi, pengeluaran pemerintah dan selisih ekspor impor. Produk Domestik Bruto merupakan salah satu indikator penting untuk mengatasi kondisi ekonomi di suatu negara dalam suatu periode tertentu, baik atas dasar harga berlaku maupun atas dasar harga konstan. ( Tabrizi, $2014: 28$ ).

Berikut adalah perkembangan PDB periode 2015-2018 yang menjadi sampel penelitian:

Tersedia online : http://jurnal.stesislamicvillage.ac.id/index.php/JURNAL 


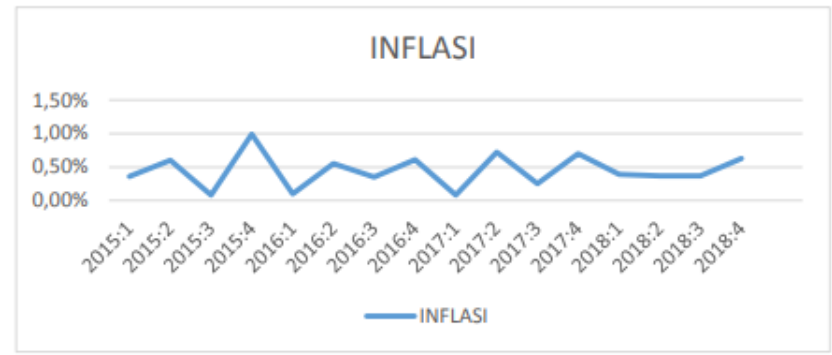

Gambar 4.6

Perkembangan Inflasi di Banten Periode 2015-2018

Sumber : Laporan Keuangan Masing-masing BPRS (Data Diolah)

PDB terendah terjadi di triwulan IV tahun 2015 sebesar 4.87\%, Sedangkan PDB tertinggi terjadi di triwulan IV tahun 2018 sebesar $5.98 \%$ pada Provinsi Banten selama 4 tahun terakhir. Terlihat pada gambar 4.6 PDB selama 4 mengalami fluktiatif dengan nilai rata - rata sebesar $5.55 \%$

\section{Hasil Analisis Data}

Keputusan untuk memilih jenis model yang gunakan dalam analisis panel berdasarkan pada dua uji yaitu uji chow dan uji hausmant. Uji chow digunakan untuk memutuskan apakah menggunakan Common Effect atau Fixed Effect sedangkan keputusan menggunakan Fixed Effect atau Random Effect ditentukan oleh uji hausmant.

Dalam pengolahan data panel, mekanisme uji menentukan metode pemilihan data panel yang tepat yaitu dengan cara membandingkan metode pendekatan Common Effect Model (CEM) dengan metode pendekatan Fixed Effect Model (FEM) terlebih dahulu. Jika hasil yang diperoleh menunjukan pendekatan CEM yang diterima, maka pendekatan CEM yang dianalisis.

Jika model pendekatan FEM yang diterima, maka dilakukan perbandingan lagi dengan model pendekatan Random Effect Model (REM). Maka harus membandingkan model uji chow dan model uji hausmant terlebih dahulu untuk mendapatkan model yang terbaik dalam analisis panel data.

1 Uji Chow

Pengujian Uji Chow dengan menggunakan uji likelihood ratio, lalu yang menjadi dasar penolakan dalam hipotesis di atas adalah dengan membandingkan nilai probabilitasnya dengan $\alpha=5 \%$. Perbandingan yang dimaksud adalah apabila nilai probabilitas lebih kecil dari 0,05 maka Ho ditolak sehingga dalam penelitian ini menggunakan Fixed Effect Model dan perlu melakukan Hausman test. Namun sebaliknya jika nilai probabilitasnya lebih besar dari 0,05 maka model yang tepat digunakan adalah Common Effect Model dan tidak perlu dilakukan uji Hausman. Hasil Uji Chow dalam penelitian ini menggunakan eviews 9.0 dengan hasil sebagai berikut :

\section{Tabel 4.1}

\section{Hasil Uji Chow}

\begin{tabular}{|c|c|c|c|}
\hline $\begin{array}{l}\text { Redundant Fixed Effects T } \\
\text { Equation: Untitled } \\
\text { Test cross-section fixed ef }\end{array}$ & & & \\
\hline Effects Test & Statistic & d.f. & Prob. \\
\hline Cross-section F & 33.353280 & $(7,115)$ & 0.0000 \\
\hline Cross-section Chi-square & 141.904450 & 7 & 0.0000 \\
\hline
\end{tabular}

Sumber : Eviws 9.0 (data diolah)

Berdasarkan tabel 4.1 tersebut, dapat dilihat bahwa nilai probabilitas Cross-section Chi-square adalah $0.0000<0,05$ maka digunakan adalah model FEM.

2 Uji Hausman

Tersedia online : http://jurnal.stesislamicvillage.ac.id/index.php/JURNAL 
Statistik uji hausman ini dengan melihat nilai probabilitas. Jika nilai probabilitas $<0,05$ (untuk tingkat signifikansi $=0,05)$ maka Ho ditolak dan model yang lebih tepat adalah Fixed Effect Model (FEM), begitupun sebaliknya. Bila nilai probabilitas > 0,05, maka model yang lebih tepat adalah Random Effect Model (REM).

Tabel 4.2

Hasil Uji Hausman

Correlated Random Effects - Hausman Test

Equation: Untitled

Test cross-section random effects

\begin{tabular}{lrrr}
\hline \hline Test Summary & $\begin{array}{r}\text { Chi-Sq. } \\
\text { Statistic }\end{array}$ & Chi-Sq. d.f. & Prob. \\
\hline \hline Cross-section random & 106.628983 & 5 & 0.0000 \\
\hline \hline
\end{tabular}

Sumber : Eviws 9.0 (data diolah)

Berdasarkan tabel 4.3 tersebut, dapat dilihat bahwa nilai propitabilitas Cross-section Chi-square adalah $0.0000<0,05$ maka digunakan adalah model FEM.

\section{Hasil Uji Asumsi Klasik}

\section{Uji Normalitas}

Uji normalitas dalam pengujian ini bertujuan untuk menguji apakah dalam model regresi, variabel pengganggu atau residual memliki distribusi normal. Model regresi yang baik adalah memiliki distribusi data normal atau mendekati normal. Dalam penelitian ini akan menggunakan metode J-B Test, jika nilai probabilitas J-B Test lebih besar dari nilai taraf nyata 0.05 , maka data tersebut berdistribusi normal. Berdasarkan hasil pengolahan data menggunakan Eviews 9.0 hasil pengujiannya, sebagi berikut:

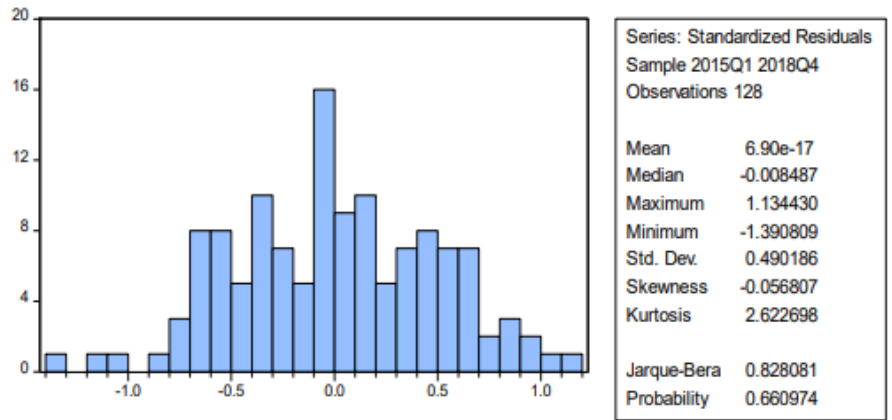

Gambar 4.7

\section{Hasil Uji Jarque-Bera}

Sumber : Lampiran 1, pengolahan data dengan Eviews

Dari hasil output menggunakan program eviews 9.0 didapatkan bahwa nilai Probabilitas JarqueBera (JB) sebesar 0.6660974 dalam pengolahan data ini mengunakan, sehingga dapat disimpulkan nilai Probabilitas Jarque-Bera (JB) $0.6660974>0.05$ yang menunjukan data tersebut berdistribusi normal.

2. Uji Multikolinearitas

Masalah multikolinearitas adalah situasi dimana adanya korelasi antara variabel bebas dengan variabel bebas lainnya. Untuk mengetahui ada atau tidaknya multikolinearitas digunakan uji correlation dengan menggunakan matriks korelasi. Jika koefisien korelasi pada output menunjukan hasil di atas 0,8 maka diduga terjadi multikolinearitas. Sebaliknya jika koefisien korelasi rendah di

Tersedia online : http://jurnal.stesislamicvillage.ac.id/index.php/JURNAL 
bawah 0,8 maka diduga model tidak mengandung multikolinearitas. Berdasarkan hasil uji multikolinearitas yang dilakukan dengan Eviews 9.0 diperoleh hasil sebagai berikut:

Tabel 4.3

Uji Multikolinearitas

\begin{tabular}{|l|l|l|l|l|l|}
\hline Variabel & Bagi Hasil & FDR & Suku Bunga & Inflasi & PDB \\
\hline Bagi Hasil & 1 & 0.361942 & -0.043989 & 0.172055 & 0.046334 \\
\hline FDR & 0.361942 & 1 & 0.013896 & 0.031724 & -0.021476 \\
\hline Suku Bunga & -0.043989 & 0.013896 & 1 & -0.067490 & 0.102643 \\
\hline Inflasi & 0.172055 & 0.031724 & -0.067490 & 1 & -0.223289 \\
\hline PDB & 0.046334 & -0.021476 & 0.102643 & -0.223289 & 1 \\
\hline
\end{tabular}

Sumber : Lampiran 2, pengolahan data dengan Eviews

Berdasarkan hasil pengujian multikolinearitas pada tabel 4.3, dapat dilihat bahwa nilai seluruh pada antar masing-masing variable bebas berada di bawah 0,80 . Sehingga dapat disimpulkan bahwa model regresi yang dipakai tidak terdapat masalah multikolinearitas.

3. Uji Heteroskedastisitas

Uji heteroskedastisitas digunakan untuk mengetahui ada atau tidaknya penyimpangan asumsi klasik heteroskedastisitas yaitu adanya ketidaksamaan varian dari residual untuk semua pengamatan pada model regresi. Dalam penelitian ini digunakan uji glejser, uji dapat menjelaskan apabila nilai Probabilitas F-statistic lebih $\alpha=5 \%$ maka data bersifat heteroskedastisitas begitu pula sebaliknya.

\section{Tabel 4.4}

\section{Uji Heteroskedastisitas}

Heteroskedasticity Test: Glejser

\begin{tabular}{llll}
\hline \hline & & & \\
F-statistic & 2.139710 & Prob. F(5,122) & 0.0652 \\
Obs*R-squared & 10.31974 & Prob. Chi-Square(5) & 0.0667 \\
Scaled explained SS & 9.511577 & Prob. Chi-Square(5) & 0.0903 \\
\hline \hline
\end{tabular}

Sumber : Lampiran 3, pengolahan data dengan Eviews

Hasil output pada table 4.4 menunjukan nilai Prob. F-statistic adalah sebesar 0,0667 > daripada $\alpha=0,05$. Dengan demikian dapat disimpulkan bahwa data tidak mengandung heteroskedastisitas

\section{Uji Autokorelasi}

Autokorelasi adalah korelasi antara residual satu observasi dengan residual observasi lainnya. Autokorelasi lebih mudah timbul pada data runtut waktu (time series) karena berdasarkan sifatnya, data masa sekarang dipengaruhi oleh data pada masa sebelumnya. Metode pengujian menggunakan uji Durbin-Watson (DW-test) yaitu dengan ketentuan sebagai berikut:

- Bila DW terletak antara batas atas (du) dan (4-du), maka koefisien autokorelasi sama dengan nol, berarti tidak ada autokorelasi.

- Bila nilai DW lebih rendah dari pada batas bawah (dl), maka koefisien autokorelasi lebih besar dari pada nol, berarti ada autokorelasi positif.

Tersedia online : http://jurnal.stesislamicvillage.ac.id/index.php/JURNAL 
- Bila nilai DW lebih besar dari pada (4-dl), maka koefisien autokorelasi lebih kecil dari pada nol, berarti ada autokorelasi negatif.

- Bila nilai DW terletak diantara batas atas (du) dan batas bawah (dl) ada DW terletak antara (4du) dan (4-dl), maka hasilnya tidak dapat disimpulkan.

- Bila nilai DW terletak antara (4-du) dan (4-dl), maka hasilnya tidak dapat disimpulkan.

Durbin-Watson (DW-test) dapat dilihat pada tabel berikut:

Tabel 4.5

Uji Autokorelasi

\begin{tabular}{|l|l|l|}
\hline \multirow{2}{*}{ Durbin-Watson } & Durbin-Watson tabel 5\% \\
\cline { 2 - 3 } & $\mathrm{Dl}$ & $\mathrm{Du}$ \\
\hline 2.093260 & 1.6312 & 1.7932 \\
\hline
\end{tabular}

Sumber : Lampiran 4, pengolahan data dengan Eviews

Hasil output pada table 4.5 di atas diketahui bahwa:

- Uji statistik DW = 2.093260

$\mathrm{dl}=1.6312$

$(4-\mathrm{dl})=2,3688$

$\mathrm{du}=1.7932$

$(4-\mathrm{du})=2,2068$

Nilai DW terletak diantara du dan (4-du)

- Keputusan

Hasil perhitungan diatas bahwa nilai DW sebesar 2.093260 terletak diantara nilai du dan (4-du) sebesar 1.7932 dan 2,2068 (du < DW < 4-du) maka dapat disimpulkan bahwa tidak ada autokorelasi dalam model regresi yang digunakan dalam penelitian ini.

\section{Pengujian Hipotesis}

1. Uji Parsial (Uji t)

Uji t dilakukan untuk melihat signifkansi dari pengaruh variabel bebas secara individu terhadap variabel terikat dengan menganggap variabel bebas lainnya adalah konstan. Pada tingkat signifikansi $0,05(5 \%)$ berikut hasil uji t statistik:

Tabel 4.6

Uji Arah Parsial (t-Statistik)

\begin{tabular}{|c|c|c|c|c|}
\hline Variabel & t-Statistik & t-Tabel & Probabilitas & Hasil \\
\hline Bagi Hasil & 1.753932 & \multirow{5}{*}{1.65734} & 0.0414 & $\mathrm{H}_{0}$ ditolak \\
\hline$\overline{F D R}$ & -2.073472 & & 0.0408 & $\mathrm{H}_{0}$ ditolak \\
\hline Suku Bunga & -2.669178 & & 0.0089 & $\mathrm{H}_{0}$ ditolak \\
\hline Inflasi & -3.693169 & & 0.0004 & $\mathrm{H}_{0}$ ditolak \\
\hline PDB & -0.160482 & & 0.8728 & $\mathrm{H}_{0}$ diterima \\
\hline
\end{tabular}

Sumber : Lampiran 5, pengolahan data dengan Eviews

Tersedia online : http://jurnal.stesislamicvillage.ac.id/index.php/JURNAL 
Tabel 4.6 merupakan hasil dari pengujian variabel independen yaitu tingkat bagi hasil deposito mudharabah, FDR, suku bunga , inflasi, dan PDB terhadap jumlah deposito mudharabah pada Bank Pembiayaan Rakyat Syariah di Provinsi Banten tahun 2015-2018, berikut intepretasi untuk secara parsial (Uji t) :

a. Pengaruh bagi hasil terhadap deposito mudhrabah, diketahui Uji t terhadap variabel tingkat bagi hasil deposito mudharabah hasil yang didapat pada tabel 4.6 variabel tingkat bagi hasil deposito mudharabah secara statistik menunjukkan hasil yang signifikan pada nilai probabilitas lebih kecil dari $\alpha(0.0414<0,05)$. Sedangkan nilai t hitung X1 = 1.753932 dan $\mathrm{t}$ tabel sebesar $1.65734(\mathrm{df}(\mathrm{n}-$ k) $128-5=123, \alpha=0,05)$, sehingga t hitung $<\mathrm{t}$ tabel $(1.753932>1.65734)$. Maka H0 tolak sehingga dapat disimpulkan bahwa variabel tingkat bagi hasil deposito mudharabah berpengaruh positif signifikan terhadap jumlah deposito mudharabah, yaitu ketika tingkat bagi hasil deposito mudharabah naik nilainya maka jumlah deposito mudharabah akan naik juga nilainya signifikan, sehingga dapat dikatakan bahwa setiap kenaikan jumlah deposito mudharabah bukan dipengaruhi oleh tingkat bagi hasil deposito mudharabah.

b. Pengaruh FDR terhadap deposito mudhrabah, diketahui Uji t terhadap variabel FDR terhadap deposito mudharabah hasil yang didapat pada tabel 4.6 variabel FDR secara statistik menunjukkan hasil yang signifikan pada nilai probabilitas lebih kecil dari $\alpha(0.0408<0,05)$. Sedangkan nilai $t$ hitung X2 = - 2.073472dan t tabel sebesar $1.65734(\mathrm{df}(\mathrm{n}-\mathrm{k}) 128-5=123, \alpha=0,05)$, sehingga $\mathrm{t}$ hitung > t tabel $(-2.073472>1.65734)$. Maka H0 ditolak sehingga dapat disimpulkan bahwa variabel FDR berpengaruh negatif signifikan terhadap jumlah deposito mudharabah, yaitu ketika FDR naik nilainya maka jumlah deposito mudharabah akan nurun nilainya dan sebaliknya, sehingga dapat dikatakan bahwa setiap kenaikan jumlah deposito mudharabah dipengaruhi oleh FDR.

c. Pengaruh suku bunga terhadap deposito mudhrabah, diketahui Uji t terhadap variabel suku bunga terhadap deposito mudharabah hasil yang didapat pada tabel 4.6 variabel suku bunga secara statistik menunjukkan hasil yang signifikan pada nilai probabilitas lebih kecil dari $\alpha(0.0089<0,05)$. Sedangkan nilai t hitung X3 = -2.669178 dan t tabel sebesar 1.65734 (df (n-k) 128-5 =123, $\alpha=$ $0,05)$, sehingga $t$ hitung $>\mathrm{t}$ tabel $(-2.669178>1.65734)$. Maka H0 ditolak sehingga dapat disimpulkan bahwa variabel suku bunga berpengaruh negatif signifikan terhadap jumlah deposito mudharabah, yaitu ketika suku bunga naik nilainya maka jumlah deposito mudharabah akan nurun nilainya dan sebaliknya, sehingga dapat dikatakan bahwa setiap kenaikan jumlah deposito mudharabah dipengaruhi oleh suku bunga.

d. Pengaruh inflasi terhadap deposito mudhrabah, diketahui Uji t terhadap variabel inflasi terhadap deposito mudharabah hasil yang didapat pada tabel 4.6 variabel inflasi secara statistik menunjukkan hasil yang signifikan pada nilai probabilitas lebih kecil dari $\alpha(0.0004<0,05)$. Sedangkan nilai t hitung X4 = -3.693169 dan t tabel sebesar 1.65734 (df (n-k) 128-5 = 123, $\alpha=$ $0,05)$, sehingga $t$ hitung $>\mathrm{t}$ tabel $(-3.693169>1.65734)$. Maka HO ditolak sehingga dapat disimpulkan bahwa variabel inflasi berpengaruh negatif signifikan terhadap jumlah deposito mudharabah, yaitu ketika inflasi naik nilainya maka jumlah deposito mudharabah akan nurun nilainya dan sebaliknya, sehingga dapat dikatakan bahwa setiap kenaikan jumlah deposito mudharabah dipengaruhi oleh inflasi.

e. Pengaruh PDB terhadap deposito mudhrabah, diketahui Uji t terhadap variabel PDB terhadap deposito mudharabah hasil yang didapat pada tabel 4.6 variabel PDB secara statistik menunjukkan hasil yang signifikan pada nilai probabilitas lebih kecil dari $\alpha(0.8728>0,05)$. Sedangkan nilai $t$ hitung X5 = - 0.160482 dan $\mathrm{t}$ tabel sebesar 1.65734 (df $(\mathrm{n}-\mathrm{k}) 128-5=123, \alpha=0,05)$, sehingga $\mathrm{t}$ hitung < t tabel $(-0.160482<1.65734)$. Maka H0 diterima sehingga dapat disimpulkan bahwa variabel PDB berpengaruh negatif tidak signifikan terhadap jumlah deposito mudharabah, yaitu ketika inflasi naik nilainya maka jumlah deposito mudharabah akan nurun nilainya dan sebaliknya namun tidak signifikan, sehingga dapat dikatakan bahwa setiap kenaikan jumlah deposito mudharabah bukan dipengaruhi oleh PDB.

Tersedia online : http://jurnal.stesislamicvillage.ac.id/index.php/JURNAL 
2. Hasil Uji Kebaikan Model (Uji F)

Uji Signifikansi Simultan (Uji F) Untuk menguji apakah variabel independen berpengaruh secara simultan terhadap variabel dependen, Pedoman yang digunakan dalam pengambilan kesimpulan uji $\mathrm{F}$ adalah sebagai berikut:

Jika F-hitung < F-tabel, maka H0 diterima dan H1 ditolak Jika F-hitung > F-tabel, maka H0 ditolak dan $\mathrm{H} 1$ diterima

Selain itu, dapat pula dilihat dari probabilitas F statistik. Apabila probabilitas (signifikansi) lebih kecil dari nilai $\alpha=5 \%$, maka dapat disimpulkan bahwa seluruh variabel independen secara simultan berpengaruh signifikan terhadap variabel dependen.

Adapun hipotesisnya adalah sebagai berikut: H0: tingkat bagi hasil deposito mudharabah, FDR, suku buga, inflasi dan PDB tidak berpengaruh terhadap jumlah deposito mudharabah pada Bank Pembiayaan Rakyat Syariah di Provinsi Banten secara simultan.

Tabel 4.7

Hasil Uji F Statistik

\begin{tabular}{|c|c|}
\hline F- Statistik & F Tabel \\
\hline 1540.849 & 2.45 \\
\hline
\end{tabular}

Sumber : Lampiran 6, pengolahan data dengan Eviews

Berdasarkan Tabel 4.7, diperoleh hasil F-statistik atau $\mathrm{F}$ hitung sebesar 1540.849 dengan nilai probabilitas sebesar 0.00000. nilai probabilitas tersebut lebih kecil dari $\alpha=5 \%$. Selain itu dengan $n=$ 128 dan $\mathrm{k}=5$, nilai pada $\mathrm{F}$ tabel diperoleh nilai 2.45 Dengan df1 (k-1) dan df2 (n-k) sebesar 4 dan 123 dengan nilai probabilitas 5\%. Karena F hitung > F tabel $(1540.849>2,45)$ maka H0 ditolak, artinya dapat disimpulkan bahwa variabel tingkat bagi hasil deposito mudharabah, FDR, suku bunga, inflasi, dan PDB berpengaruh signifikan secara simultan terhadap jumlah deposito mudhrabah pada Bank Pembiayaan Rakyat Syariah di Provinsi Banten.

3. Hasil Uji Koefisien Determinasi $\left(\mathrm{R}^{2}\right)$

Uji Adjusted R2 ditujukan untuk menilai seberapa besar kemampuan variabel independen menjelaskan variabel dependen. Pada penelitian ini, koefisien yang digunakan adalah koefisien determinasi yang telah disesuaikan atau adjusted $R^{2}$. Hal ini dikarenakan adjusted $\mathrm{R}^{2}$ merupakan koefisien yang telah dikoreksi sehingga dapat naik atau turun seiring penambahan variabel baru dalam model.

Tabel 4.8

Uji Koefisien Determinasi

\begin{tabular}{|l|l|}
\hline$R$-Squared & Adjusted R-Squared \\
\hline 0.995524 & 0.994877 \\
\hline
\end{tabular}

Sumber : Lampiran 7, pengolahan data dengan Eviews

Berdasarkan hasil regresi dengan Fixed Effect Model sebagaimana yang tertera pada tabel, diketahui bahwa nilai Adjust $R$ Squared sebesar 0.995524. Hal ini menunjukan bahwa variasi variabel dependen (jumlah deposito mudharabah) secara simultan dapat dijelaskan oleh variabel independen (tingkat bagi hasil deposito mudharabah, FDR, suku bunga , inflasi, dan PDB) sebesar 99,55\% sedangkan sisanya $0,45 \%$ dijelaskan oleh faktor lain diluar variabel yang diteliti.

Tersedia online : http://jurnal.stesislamicvillage.ac.id/index.php/JURNAL 


\section{Hasil Persamaan Regresi dan Pembahasan}

1. Hasil Persamaan Regresi Data Panel : Pengaruh Tingkat Bagi Hasil Deposito Mudharabah, FDR, Suku Bunga, Inflasi, Dan PDB Terhadap Jumlah Deposito Mudharabah

Dalam regresi Pengaruh Tingkat Bagi Hasil Deposito Mudharabah, FDR, Suku Bunga, Inflasi, Dan PDB Terhadap Jumlah Deposito Mudharabah pada Bank Pembiayan Rakyat Syariah di Provinsi Banten dengan menggunakan metode FEM:

\begin{tabular}{|c|c|c|c|c|}
\hline \multicolumn{5}{|c|}{$\begin{array}{l}\text { Dependent Variable: DEPOSI? } \\
\text { Method: Pooled EGLS (Cross-section SUR) } \\
\text { Date: } 11 / 11 / 19 \text { Time: } 11: 43 \\
\text { Sample (adjusted): } 2015 \mathrm{~s} 32018 \mathrm{Q} 4 \\
\text { Included observations: } 14 \text { after adjustments } \\
\text { Cross-sections included: } 8 \\
\text { Total pool (balanced) observations: } 112 \\
\text { Iterate coefficients after one-step weighting matrix } \\
\text { Cross-section SUR (PCSE) standard errors \& covariance (d.f. corrected) } \\
\text { Convergence achieved after } 15 \text { total coef iterations }\end{array}$} \\
\hline Variable & Coefficient & Std. Error & t-Statistic & Prob. \\
\hline C & 5743653. & 441195.1 & 13.01840 & 0.0000 \\
\hline LNBH? & 14666.21 & 12709.77 & 1.173932 & 0.0414 \\
\hline LNFDR? & -117423.4 & 56631.27 & -2.073472 & 0.0408 \\
\hline LNSB? & -30461.36 & 11412.26 & -2.669178 & 0.0089 \\
\hline LNINF? & -27506.68 & 7447.987 & -3.693169 & 0.0004 \\
\hline LNPDB? & -19181.35 & 119523.1 & -0.160482 & 0.8728 \\
\hline $\mathrm{AR}(1)$ & 0.913022 & 0.106720 & 8.555317 & 0.0000 \\
\hline $\operatorname{AR}(2)$ & -0.192921 & 0.096440 & -2.000421 & 0.0483 \\
\hline \multicolumn{5}{|c|}{ Fixed Effects (Cross) } \\
\hline BPRSA--C & -4725962 & & & \\
\hline BPRSBR--C & -1774497 & & & \\
\hline BPRSCM--C & -4634766 & & & \\
\hline BPRSHI--C & 29037576 & & & \\
\hline BPRSMBA-CC & -926902.4 & & & \\
\hline BPRSMC--C & -5570953 & & & \\
\hline
\end{tabular}

\begin{tabular}{|c|c|c|c|}
\hline $\begin{array}{l}\text { BPRSMUI--C } \\
\text { BPRSW--C }\end{array}$ & \multicolumn{3}{|l|}{$\begin{array}{l}-5713771 \\
-5690725\end{array}$} \\
\hline \multicolumn{4}{|c|}{ Effects Specification } \\
\hline \multicolumn{4}{|c|}{ Cross-section fixed (dummy variables) } \\
\hline \multicolumn{4}{|c|}{ Weighted Statistics } \\
\hline R-squared & 0.995524 & Mean dependent var & 7.372815 \\
\hline Adjusted R-squared & 0.994877 & S.D. dependent var & 11.92614 \\
\hline S.E. of regression & 0.999535 & Sum squared resid & 96.90981 \\
\hline F-statistic & 1540.849 & Durbin-Watson stat & 2.093260 \\
\hline Prob(F-statistic) & 0.000000 & & \\
\hline \multicolumn{4}{|c|}{ Unweighted Statistics } \\
\hline R-squared & 0.997922 & Mean dependent var & 5963945. \\
\hline Sum squared resid & $2.80 \mathrm{E}+13$ & Durbin-Watson stat & 2.376726 \\
\hline
\end{tabular}

Gambar 4.8

\section{Hasil Regresi Data Panel}

Dalam regresi Pengaruh Tingkat Bagi Hasil Deposito Mudharabah, FDR, Suku Bunga, Inflasi, Dan PDB Terhadap Jumlah Deposito Mudharabah pada Bank Pembiayan Rakyat Syariah di Provinsi Banten dengan menggunakan metode Fixed Effect Model ( FEM ) berikut adalah persamaan nonlinier data panel :

Berikut hasil regresi data panel dengan menggunakan metode Fixed Effect Model ( FEM ) :

DEPOSI $=5743653+14666.2103197$ LnBH -117423.351982 LnFDR -30461.3566446 LnSB27506.6786173 LnINF - 19181.3482634 Ln PDB + et

\section{Pembahasan}

1. Nilai Konstan Terhadap Deposito Mudharabah

Didapat bahwa nilai kostan dalam persamaan regresi sebesar 5743653 maka artinya bahwa ketika nilai variabel independen tingkat bagi hasil deposito mudharabah, FDR, suku bunga, inflasi, dan PDB terhadap jumlah deposito mudharabah sama dengan nol maka nilai variabel dependen profitabilitas sebesar 5743653.

2. Pengaruh Tingkat Bagi Hasil Terhadap Deposito Mudharabah

Tingkat Bagi Hasil (rate of return) adalah tingkat pengembalian bersih atas modal/investasi atau dana yang disimpan di perbankan. Dalam perbankan syariah, tingkat bagi hasil (rate of return) bergantung pada besar kecilnya nisbah yang diberikan dan laba yang diperoleh oleh bank (Sutan, 2014:31).

Hubungan tingkat bagi hasil deposito mudharabah terhadap jumlah deposito mudharabah Hasil estimasi pada gambar 4.8 menjelaskan variabel tingkat bagi hasil deposito mudharabah mempunyai pengaruh positif dan signifikan terhadap jumlah deposito mudharabah, dimana setiap kenaikan tingkat bagi hasil deposito mudharabah sebesar $1 \%$ akan meningkatkan jumlah deposito mudharabah sebesar nilai koefisien regresinya yaitu $1.753932 \%$.

Tersedia online : http://jurnal.stesislamicvillage.ac.id/index.php/JURNAL 
Hal ini menjelaskan bahwa semakin tinggi tingkat bagi hasil yang ditawarkan oleh bank syariah kepada nasabah maka akan meningkatkan jumlah simpanan mudharabah yang dihimpun bank syariah. Penyebab dari hubungan positif antara tingkat bagi hasil terhadap simpanan mudharabah yaitu karena para nasabah pada umumnya menabungkan dananya pada bank syariah dikarenakan mereka masih mencari keuntungan (profit maximitation). Hasil penelitian ini mendukung penelitian yang dilakukan oleh Juniarty dkk (2017), Rahman dkk (2013), Sayid dkk (2014) Ruslizar dan Rahmawaty (2016), Hilman (2016), Arif dkk (2017), Islami (2018) Sholikha (2018), dan Rahayu dkk (2018) menyatakan bahwa tingkat bagi hasil mempunyai pengaruh yang positif dan signifkan terhadap jumlah deposito mudharabah dikarenakan nasabah menyimpan dananya karena faktor mencari keuntungan.

\section{Pengaruh FDR Terhadap Deposito Mudharabah}

Financing To Deposit Ratio adalah rasio yang menggambarkan tingkat kemampuan bank syariah dalam mengembalikan dana nasabah sebagai pihak ketiga melalui pendapatan yang diperoleh dari pembiayaan mudharabah (Rivai, V., dan Arifin, 2010).

Hubungan FDR terhadap jumlah deposito mudharabah Hasil estimasi pada gambar 4.8 menjelaskan variabel FDR mempunyai pengaruh negatif dan signifikan terhadap jumlah deposito mudharabah, dimana setiap kenaikan FDR sebesar 1\% akan mengurangi jumlah deposito mudharabah sebesar nilai koefisien regresinya yaitu $-2.073472 \%$.

Hal ini mendukung penelitian Andriyanti dan Wasilah (2010), Fadli ( 2018), Febriani (2019) , yang menunjukkan bahwa tingkat likuiditas memiliki kecenderungan negatif terhadap deposito mudharabah. Semakin tinggi rasio FDR menandakan bahwa semakin rendah kemampuan likuiditas bank tersebut,karena FDR yang terlampau tinggi menunjukkan jumlah DPK yang tidak mampu menutupi pembiayaan yang disalurkan. Sehingga nasabah akan memperhitungkan kembali untuk menyimpan dananya di bank tersebut dan cenderung untuk menarik dananya, karena nasabah akan menghindari risiko likuiditas yang mungkin akan dihadapi oleh bank. Pemicu utama kebangkrutan yang dialami oleh bank baik yang besar maupun yang kecil, bukanlah karena kerugian yang dideritanya, melainkan lebih kepada ketidakmampuan bank untuk memenuhi likuiditasnya. Likuiditas yang tersedia harus cukup, tidak boleh terlalu kecil sehingga mengganggu kebutuhan operasional sehari- hari,tetapi tidak boleh terlalu besar karena akan menurunkan efisiensi dan berdampak pada rendahnya tingkat profitabilitas. Maka dari itu dapat disimpulkan karena kekhawatiran masyarakat akan risiko likuiditas, apabila rasio FDR semakin tinggi, maka jumlah deposito mudharabah akan turun.

4. Pengaruh Tingkat Suku Bunga Terhadap Deposito Mudharabah

Menurut Kasmir, bunga juga dapat diartikan sebagai harga yang harus dibayar kepada nasabah (yang memiliki simpanan) dengan yang harus dibayar oleh nasabah kepada bank (nasabah yang memperoleh pinjaman). Sedangkan suku bunga adalah rasio dari bunga terhadap jumlah pinjaman. (Kasmir, $2012: 121$ ).

Hubungan suku bunga terhadap jumlah deposito mudharabah Hasil estimasi pada gambar 4.8 menjelaskan variabel suku bunga mempunyai pengaruh negatif dan signifikan terhadap jumlah deposito mudharabah, dimana setiap kenaikan suku bunga sebesar $1 \%$ akan mengurangi jumlah deposito mudharabah sebesar nilai koefisien regresinya yaitu $-2.669178 \%$.

Dengan meningkatnya suku bunga akan menyebabkan peningkatan risiko displacement fund ( pengalihan dana dari bank syariah ke bank konvensional) yang akan dihadapi bank syariah. Hal ini tentunya akan membuat jumlah dana pihak ketiga yang dihimpun oleh bank syariah menurun. Adapun pengalihan dana yang terjadi dikarenakan masih banyak mayoritas nasabah - nasabah bank syariah yang menjadikan tingkat suku bunga sebagai acuan dalam penempatan dana untuk kegiatan invenstasi. Hasil penelitian ini mendukung dengan penelitian sebelum nya yang dilakukan oleh Rahman, dkk (2013), Lestari dan Trikunawangsih (2014), Prasetya, dkk (2015), Ruslizar dan Rahmawaty (2016), Iim (2016), Meutia (2017), Baehaqie dkk (2017), Sholikha (2018), Rahayu dkk (2018), yang telah menunjukkan bahwa tingkat suku bunga bank konvensional memiliki pengaruh negatif terhadap dana

Tersedia online : http://jurnal.stesislamicvillage.ac.id/index.php/JURNAL 
pihak ketiga bank syariah.

5. Pengaruh Inflasi Terhadap Deposito Mudharabah

Inflasi adalah gejala ekonomi yang menunjukkan naik tingkat harga secara umum yang berkesinambungan. Syarat inflasi yanitu terjadi kenaikan harga secara umum dan terus menerus. Jika satu dua jenis barang saja yang naik, itu bukan merupakan inflas, kenaikan harga yang bersifat sementara, umpamanya kenaikan harga karen amusiman, menjelang hari raya, bencana, dan sebgainya, tidak disebut inflasi ( Hasyim, $2016: 186$ ).

Hubungan Inflasi terhadap jumlah deposito mudharabah Hasil estimasi pada gambar 4.8 menjelaskan variabel Inflasi mempunyai pengaruh negatif dan signifikan terhadap jumlah deposito mudharabah, dimana setiap kenaikan Inflasi sebesar $1 \%$ akan mengurangi jumlah deposito mudharabah sebesar nilai koefisien regresinya yaitu $-3.693169 \%$.

Hal ini dikarenakan masyarakat tentunya akan mengutamakan memenuhi kebutuhan pokok mereka terlebih dahulu sebelum menginvestasikan dana mereka. Karena kenaikan inflasi akan mempengaruhi perekonomian yang akan berimbas pada kenaikan bahan-bahan untuk memenuhi kebutukan masyarakat dan hal itu tentu inflasi akan mengakibatkan kurangnya minat masyarkat untuk mendepositkan dananya dikarenakan karena ketidaktersedian dana lebih yang dimiliki masyarkat untuk berinvestasi. Sesuai dengan teori Keynes "inflasi terjadi karena suatu masyarakat ingin hidup diluar batas kemampuan ekonominya". Proses inflasi menurut pandangan ini, tidak lain adalah proses perebutan bagian rezeki diantara kelompok-kelompok yang menginginkan bagian yang lebih besar dari pada yang bisa disediakan oleh masyarakat tersebut proses perebutan ini akhirnya diterjemahkan menjadi keadaan dimana permintaan masyarakat akan barang-barang selalu melebihi jumlah barangbarang yang tersedia (inflatiory gap). Hasil penelitian ini konsisten dengan penelitian sebelumnya yang ditunjukkan oleh Abduh dkk (2011)Diah (2014), Nisa dkk (2015), Arshad dan Nurfadilah (2017) dan, Rosid (2017).Dalam penelitiannya menjelaskan bahwa inflasi secara signifikan mempengaruhi jumlah dana pihak ketiga (giro, tabungan, deposito) perbankan syariah. Apabila terjadi inflasi jumlah DPK akan mengalami penurunan, diakibatkan oleh penarikan dana oleh nasabah untuk memenuhi kebutuhan konsumsi.

\section{Pengaruh PDB Terhadap Deposito Mudharabah}

Produk Domestik Bruto adalah jumlah semua barang dan jasa yang dihasilkan oleh sesuatu negara dalam periode tertentu. Komponen yang ada dalam PDB yaitu pendapatan, investasi, pengeluaran pemerintah dan selisih ekspor impor. Produk Domestik Bruto merupakan salah satu indikator penting untuk mengatasi kondisi ekonomi di suatu negara dalam suatu periode tertentu, baik atas dasar harga berlaku maupun atas dasar harga konstan. ( Tabrizi, $2014: 28$ ).

Hubungan PDB terhadap jumlah deposito mudharabah Hasil estimasi pada gambar 4.8 menjelaskan variabel PDB mempunyai pengaruh negatif dan tidak signifikan terhadap jumlah deposito mudharabah, dimana setiap kenaikan PDB sebesar 1\% akan mengurangi jumlah deposito mudharabah sebesar nilai koefisien regresinya yaitu $-0.160482 \%$ namun tidak signifikan.

Berdasarkan hasil penelitian Novianto dan Hadiwidjojo (2013), Sayid dkk ( 2014) dan Sholikha (2018), menyebutkan PDB berpengaruh negatif dan tidak signifikan terhadap deposito mudharabah. Secara teori pendapatan masyarakat yang meningkat belum tentu meningkatkan jumlah simpanan mudharabah masyarkat pada bank syariah sebab kelebihan konsumsi mereka belum tentu ditabung untuk kebutuhan di masa yang akan datang.

Secara tahunan, simpanan mudharabah pada bank syariah secara umum terus mengalami peningkatan namun tidak konsisten dengan perkembanagan PDB di Provinsi Banten. Simpanan mudharabah pada bank syariah juga akan belum tentu naik apabila pendapatan masyarakat yang direpresentasikan oleh PDB juga naik.

Tersedia online : http://jurnal.stesislamicvillage.ac.id/index.php/JURNAL 


\section{KESIMPULAN}

Penelitian ini bertujuan untuk mengetahui apakah terjadi pengaruh antara tingkat bagi hasil deposito mudharabah, FDR, suku bunga, inflasi, dan PDB terhadap jumlah deposito mudharabah pada Bank Pembiayan Rakyat Syariah di Provinsi Banten periode tahun 2015 sampai dengan 2018. Berdasarkan penemuan dan pembahasan maka kesimpulan dari penelitian ini adalah sebagai berikut:

1. Tingkat bagi hasil deposito mudharabah berpengaruh positif dan signifikan terhadap jumlah deposito mudharabah pada Bank Pembiayan Rakyat Syariah di Provinsi Banten periode 2015-2018, dimana setiap kenaikan tingkat bagi hasil deposito mudharabah sebesar $1 \%$ akan meningkatkan jumlah deposito mudharabah sebesar nilai koefisien regresinya yaitu $1.753932 \%$. itu artinya bahwa semakin tinggi tingkat bagi hasil yang ditawarkan oleh bank syariah kepada nasabah maka akan meningkatkan jumlah simpanan mudharabah yang dihimpun bank syariah. Penyebab dari hubungan positif antara tingkat bagi hasil terhadap simpanan mudharabah yaitu karena para nasabah pada umumnya menabungkan dananya pada bank syariah dikarenakan mereka masih mencari keuntungan (profit maximitation).

2. FDR berpengaruh negatif dan signifikan terhadap jumlah deposito mudharabah pada Bank Pembiayan Rakyat Syariah di Provinsi Banten periode 2015-2018, dimana setiap kenaikan FDR sebesar 1\% akan mengurangi jumlah deposito mudharabah sebesar nilai koefisien regresinya yaitu $-2.073472 \%$, itu artinya bahwa tingkat likuiditas memiliki kecenderungan negatif terhadap deposito mudharabah. Semakin tinggi rasio FDR menandakan bahwa semakin rendah kemampuan likuiditas bank tersebut,karena FDR yang terlampau tinggi menunjukkan jumlah DPK yang tidak mampu menutupi pembiayaan yang disalurkan. Sehingga nasabah akan memperhitungkan kembali untuk menyimpan dananya di bank tersebut dan cenderung untuk menarik dananya, karena nasabah akan menghindari risiko likuiditas yang mungkin akan dihadapi oleh bank

3. Suku bunga berpengaruh negatif dan signifikan terhadap jumlah deposito mudharabah pada Bank Pembiayan Rakyat Syariah di Provinsi Banten periode 2015-2018, dimana setiap kenaikan suku bunga sebesar $1 \%$ akan mengurangi jumlah deposito mudharabah sebesar nilai koefisien regresinya yaitu $2.669178 \%$, itu artinya bahwa dengan meningkatnya suku bunga akan menyebabkan peningkatan risiko displacement fund ( pengalihan dana dari bank syariah ke bank konvensional) yang akan dihadapi bank syariah. Hal ini tentunya akan membuat jumlah dana pihak ketiga yang dihimpun oleh bank syariah menurun. Adapun pengalihan dana yang terjadi dikarenakan masih banyak mayoritas nasabah - nasabah bank syariah yang menjadikan tingkat suku bunga sebagai acuan dalam penempatan dana untuk kegiatan invenstasi.

4. Inflasi berpengaruh negatif dan signifikan terhadap jumlah deposito mudharabah pada Bank Pembiayan Rakyat Syariah di Provinsi Banten periode 2015-2018. dimana setiap kenaikan Inflasi sebesar $1 \%$ akan mengurangi jumlah deposito mudharabah sebesar nilai koefisien regresinya yaitu $3.693169 \%$, itu artinya masyarakat lebih mengutamakan memenuhi kebutuhan pokok mereka terlebih dahulu sebelum menginvestasikan dana mereka. Karena kenaikan inflasi akan mempengaruhi perekonomian yang akan berimbas pada kenaikan bahan-bahan untuk memenuhi kebutukan masyarakat dan hal itu tentu inflasi akan mengakibatkan kurangnya minat masyarkat untuk mendepositkan dananya dikarenakan karena ketidaktersedian dana lebih yang dimiliki masyarkat untuk berinvestasi..

5. PDB berpengaruh negatif dan tidak signifikan terhadap jumlah deposito mudharabah pada Bank Pembiayan Rakyat Syariah di Provinsi Banten periode 2015-2018, dimana setiap kenaikan PDB sebesar 1\% akan mengurangi jumlah deposito mudharabah sebesar nilai koefisien regresinya yaitu $0.160482 \%$ namun tidak signifikan. artinya ketika pendapatan meningkat tetapi jumlah deposito mudharabah menurun begitu pun sebaliknya. Pendapatan masyarakat yang meningkat belum tentu meningkatkan jumlah simpanan mudharabah masyarkat pada bank syariah sebab kelebihan konsumsi mereka belum tentu ditabung untuk kebutuhan di masa yang akan datang.

Tersedia online : http://jurnal.stesislamicvillage.ac.id/index.php/JURNAL 


\section{SARAN}

Dari hasil kesimpulan di atas, maka saran dalam penelitian ini adalah sebagai berikut:

1. Bagi Bank Pembiayan Rakyat Syariah

Perbankan syariah sebagai salah satu pilar pendukung perekenomian Indonesia selain perbankan konvensional. Peran tersebut dapat dilakukan dengan baik jika industri perbankan syariah memiliki volume usaha yang cukup ekonomis dalam menggerakkan system perekonomian di Provinsi Banten. dengan adanya temuan bahwa tingkat bagi hasil deposito mudharabah, FDR, suku, inflasi, dan PDB terhadap jumlah deposito mudharabah dengan kontribusi yang berbeda-beda. Hal ini menunjukkan bahwa bank pembiayaan rakyat syariah masih sulit untuk lepas dari dampak internal bank maupun ekonomi makro yang terjadi. Hasil penelitian ini dapat bermanfaat untuk evaluasi perkembangan sistem perbankan syariah agar tahan terhadap goncangan krisis dan dampak makroekonomi yang dapat terjadi kapanpun di Provinsi Banten khususnya pada produk deposito mudharabah dan sistem bagi hasilnya serta tingkat likuidasi BPRS. Hal yang dapat dilakukan antara lain penguatan modal, memiliki langkah antisipasi menghadapi dampak krisis dan makroekonomi, adanya sumber daya insani dan manajemen yang handal, serta sosialisasi mengenai perbankan syariah kepada masyarakat.

2. Bagi Nasabah

Hasil penelitian bahwa tingkat bagi hasil deposito mudharabah, FDR, suku bunga, inflasi, dan PDB memberikan tingkat kontribusi yang berbeda-beda terhadap jumlah deposito mudharabah. Maka penelitian ini diharapkan menjadi informasi yang penting dan akan menambah wawasan serta pengetahuan bagi nasabah BPRS terutama terkait dengan produk deposito mudharabah. Sehingga dapat dijadikan landasan dalam pengambilan keputusan terkait dengan investasi dalam bentuk deposito mudharabah.

3. Bagi Peneliti selanjutnya

Memiliki keterbatasan diantaranya periode pengamatan sehingga masih diperlukan data untuk mendapatkan hasil yang signifikan. Peneliti juga menyarankan pada penelitian yang akan datang untuk menggunakan data bulanan agar dapat terhindar dari masalah autokorelasi. Selain itu juga menambah variabel baru dengan maksud untuk mengetahui secara pasti variabel atau hal apa saja yang memiliki pengaruh lebih kuat terhadap jumlah deposito mudharabah pada Bank Pembiayaan Rakyat Syariah di Provinsi Banten. misalnya variabel BI rate, FDR, ROA, ROE, dan ukuran bank lainnya.

\section{DAFTAR PUSTAKA}

21, U.-U. N. (2008). Tentang Perbankan Syariah, Pasal 1 butir 23.

Abduh, M., Omar, M. A., \& Duasa, J. (2011). The Impact of Crisis and Macroeconomic Variables towards Islamic Banking Deposits Department of Business Administration Department of Economics , Kulliyah of Economics and Management Sciences, International Islamic University, Malaysia. American Journal of Applied Sciences, 8(12), 1413-1418.

Agung, R. slamet dan Y. (2014). Pengaruh Pembiayaan Bagi Hasil, Pembiayaan Jual Beli, Financing To Deposit Ratio (Fdr) Dan Non Performing Financing (Npf) Terhadap Profitabilitas Bank Umum Syariah Di Indonesia. Accounting Analysis Journal, 3(4), 466-474. https://doi.org/10.15294/aaj.v3i4.4208

Al-Arif, N. R. (2012). Dasar-Dasar Pemasaran Bank Syaria. Bandung: Alfabeta.

Al Arif, M. N. R., \& Hanifah, H. (2017). Determinan Deposito Pada Bank Umum Syariah: Model Regresi Panel. Jurnal Ekonomi Kuantitatif Terapan, 39-45. https://doi.org/10.24843/jekt.2017.v10.i01.p05

Ali, S., Hassan, A. A., \& Kasim, K. (2012). Macroeconomics Variables and Its Impact to Mudharabah Investment Deposits in Malaysia. Journal Finance Management, ISSN, 51, 10866-10869.

Ana, M. (2010). Pengaruh Tingkat Suku Bunga Dan Bagi Hasil Terhadap Deposito Mudharabah Bank Syariah Mandiri (Studi Kasus pada Bank Syariah Mandiri Cabang Ir. H. Djuanda Bandung). UNIVERSITAS WIDYATAMA.

Andriyanti, A., \& Wasilah. (2010). Faktor-Faktor yang Mempengaruhi Jumlah Penghimpunan Dana

Tersedia online : http://jurnal.stesislamicvillage.ac.id/index.php/JURNAL 
Pihak Ketiga (Deposito Mudharabah 1 Bulan) Bank Muamalat Indonesia (BMI). Simposium Nasional Akuntansi XIII.

Anisah, Nur, A. R. dan L. A. (2013). Faktor-Faktor Yang Mempengaruhi Pertumbuhan Deposito Mudharabah Bank Syariah. Jurnal Ilmu Dan Riset Akuntansi, 1(2), 169-186.

Anniswah, L. (2011). Pengaruh Tingkat Suku Bunga dan Bagi Hasil Terhadap Volume Deposito Mudharabah (Studi pada Bank Muamalat Indonesia Tahun 2009-2011). Skripsi. Semarang: Institut Agama Islam Negeri Walisongo.

Antonio, M. S. (2009). Bank Syariah: dari Teori ke Praktik. Jakarta: Tazkia Cendikia.

Ascarya. (2011). Akad \& Produk Bank Syariah (Cetakan Ke). Jakarta: Rajawali Pers.

Baehaqie, S., Fahmi, I., \& Beik, I. S. (2017). Determining Factors of Deposit Level of Islamic Bank in Indonesia. Al-Iqtishad: Journal of Islamic Economics, 9(2), 213-226. https://doi.org/10.15408/aiq.v9i2.5156

Che Arshad, D. N., \& Nurfadilah, D. (2017). The Factors Influencing the Changes of Deposit in Islamic Bank: Comparative Study between Malaysia And Indonesia. Journal of Islamic Banking and Finance, 5(2), 37-46. https://doi.org/10.15640/jibf.v5n2a6

Dendawijaya, L. (2009). Manajemen Perbankan. Jakarta: Ghalia Indonesia.

Dewi, S. L., \& Purbadharmaja, I. B. P. (2013). Pengaruh PAD, PMA dan Inflasi Terhadap Pertumbuhan Ekonomi Provinsi Bali. E-Jurnal EP Unud, 2(11), 502- 512.

Diah Iskandar, I. F. (2014). Penaruh Tingkat Suku Bunga, Inflasi, Dan Kurs Rupiah terhadap Deposito Mudharabah Dan Deposito Konvensional Pada Perbankan Di Indonesia. Jurnal Ilmu Ekonomi Dan Sosial, 2(3), 336-344.

Diyanto, V., \& Savitri, E. (2015). Faktor-Faktor Yang Mempengaruhi Pertumbuhan Deposito Mudharabah Bank Syariah. Pekbis Jurnal, 7(3), 185-1199.

Fadli, A. A. Y. (2018). Pengaruh Financing to Deposit Ratio (FDR) dan Non- Performing Financing (NPF) terhadap Bagi Hasil Deposito Mudharabah pada Bank Syariah Mandiri. Jurnal Maksipreneur: Manajemen, Koperasi, Dan Entrepreneurship, $\quad 8(1), \quad 98$. https://doi.org/10.30588/jmp.v8i1.391

Fatwa, D. S. N. (2000). Deposito. In No: 03/DSN-MUI/IV/2000.

Febriani, F. I. (2019). Pengaruh Tingkat Bagi Hasil, Financing to Deposit Ratio (FDR) Dan Tingkat Inflasi Terhadap Deposito Mudharabah Pada Bank Umum Syariah (BUS) Periode 2014 - 2017. Falah: Jurnal Ekonomi Syariah, 4(1), 108. https://doi.org/10.22219/jes.v4i1.8752

Firaldi, M. (2013). Analisis Pengaruh Jumlah Dana Pihak Ketiga (DPK), Non Performing Financing (NPF) Dan Tingkat Inflasi Terhadap Total Pembiayaan Yang Diberikan Oleh Bank Pembiayaan Rakyat Syariah (BPRS) Di Indonesia (Periode Januari 2007- Oktober 2012). Universitas Islam Negeri Syarif Hidayatullah Jakarta.

Hasyim, A. I. (2016). Ekonomi Makro. Jakarta: Prenadamedia Group.

Hilman, I. (2016). The Factors Affecting Mudharabah Deposits of Sharia Banking in Indonesia. International Journal of Business and Management Invention, 5(8), 56-66.

Ifham, A. (2010). Pedoman Umum Lembaga Keuangan Syariah. Jakarta: PT. Gramedia Pustaka Utama. Irham, F. (2011). Analisis Laporan Akuntansi. Bandung: ALFABETA.

Islami, A. F. (2018). Faktor - Faktor Yang Mempengaruhi Penghimpunan Deposito Mudharabah Pada Bank Pembiayaan Rakyat Syari’Ah Di Indonesia Periode 2012-2014. Inklusif (Jurnal Pengkajian Penelitian Ekonomi Dan Hukum Islam), 3(2), 121. https://doi.org/10.24235/inklusif.v3i2.2958

Ismail. (2011). Perbankan Syariah. Jakarta: Prenadamedia Group. Jimmi, H. (2014). Ekonomi Moneter. Yogyakarta: Deepublish.

Juniarty, N., Mifrahi, M. N., \& Tohirin, A. (2017). Faktor-faktor yang mempengaruhi deposito mudharabah pada bank syariah di Indonesia. Jurnal Ekonomi \& Keuangan Islam, 3(1), 36-42. https://doi.org/10.20885/jeki.vol3.iss1/art5

Karim, A. A. (2013). Bank Islam Analisis Fiqh dan Keuangan. Jakarta: Raja Grafindo Persada.

Kasmir. (2012). Bank dan Lembaga Kuangan Lainnya. Jakarta: PT. Raja Grafindo Persada.

Lestari, N. K., \& , T. (2014). Faktor-Faktor Yang Mempengaruhi Pertumbuhan Deposito Mudharabah 1

Tersedia online : http://jurnal.stesislamicvillage.ac.id/index.php/JURNAL 
Vol. 10 No. 2 (Jul-Des) 2020

e-ISSN 2684-6772

Bulan Di Bank Syariah Mandiri. Media Ekonomi, 183. https://doi.org/10.25105/me.v22i2.3174

Meutia, I. (2017). Empirical Research on Rate of Return , Interest Rate and Mudharabah Deposit International Journal of Accounting Research. International Journal of Accounting Research, 5(August), 1-5. https://doi.org/10.4172/2472-114X.1000141

Muhamad. (2014). Manajemen Dana Bank Syariah. Jakarta: RajaGrafindo Persada.

Nisa Lidya Muliawati, T. M. (2015). Analaisis Pengaruh Inflasi, Kurs, Suku Bunga dan Bagi Hasil Terhadap Deposito Pada PT. Bank Syariah Mandiri 2007-2012. Seminar Nasional Cendekiawan, (7), 735-745.

Novianto Abdullah Syakur dan Djumilah Hadiwidjojo. (2013). Analisis Faktor-faktor yang Mempengaruhi Penghimpunan Deposito Mudharabah Perbankan Syariah di Indonesia.

$$
\text { Jurnal Akuntansi, 11(4), 595-604. }
$$

https://doi.org/10.1016/j.entcs.2012.11.002

Nuraini, N. (2013). Analisa Faktor yang Mempengaruhi Manajemen Laba. Uversitas Islam Negeri Syarif Hidayatullah Jakarta.

Nurianto. (2010). Dasar-dasar Pemasaran Bank Syariah. Bandung: Alfabeta.

Perbawa, A. (2018). Factors Affecting Mudaraba Deposits on Islamic Commercial Bank in Indonesia. SSRN Electronic Journal. https://doi.org/10.2139/ssrn.2662912

Piliyanti, I., \& Wahyuni, T. (2014). Tingkat Suku Bunga Deposito, Tingakt Bagi Hasil Deposito Mudharabah, Financing to ratio, Tingkat Inflasi, Ukuran Perusahaan Serta Pengaruhnya Terhadap Pertumbuhan Deposito Mudharabah pada Bank Syariah Indonesia dan Malaysia. Jurnal Ekonomi Dan Bisnis Islam, 9(1), 1-18.

Pimada, L. M., Mawardi, I., \& Herianingrum, S. (2017). Determinants of islamic bank deposit in indonesia. Academic Research International, 8(2)(June).

Prasetya, B., Tan, S., \& Delis, A. (2015). Faktor-Faktor Yang Mempengaruhi Penghimpunan Dana Pihak Ketiga Perbankan Syariah Di Indonesia. Jurnal Perspektif Pembiayaan Dan Pembangunan Daerah, 3(2), 91-100.

Priyatno, D. (2012). Cara Kilat Belajar Analisis Data dengan SPSS 20. Yogyakarta: Andi Offset.

Raharja Putra, H. S. (2011). Panduan Praktis Manajemen Keuangan dan Akuntansi untuk Eksekutif Perusahaan (Cetakan Pe). Jakarta: Salemba Empat.

Rahayu, Sri Siregar, R. (2018). Jumlah Deposito Mudharabah Pt . Bank Negara Indonesia ( Bni ) Syariah. Jurnal Riset Akuntansi Multiparadigma, 5(1), 1-13.

Rivai, V., dan Arifin, A. (2010). Islamic Banking: Sebuah Teori, Konsep dan Aplikasi

(Edisi Pert). Jakarta: PT Bumi Aksara.

Rizki Aulia Rachman, Agung Yulianto, N. S. U. (2013). Pengaruh Bagi Hasil, Bunga, Ukuran Bank Dan Jumlah Cabang Terhadap Simpanan Mudharabah. Accounting Analysis $\quad$ Journal, 3(4), $457-$ 465. https://doi.org/https://doi.org/10.15294/aaj.v2i4

Robert, M. M. (2011). Bank Lembaga Keuangan (Armiko, Ed.). Bandung.

Rodoni, A. (2010). Manajemen keuangan (edisi pert). Jakarta: Mitra Wacana Media. Rosid, M. N. (2017). Pengaruh Inflasi, Kurs, Dan Jumlah Bagi Hasil Terhadap

Deposito Mudharabah Pada Bank Syariah Mandiri (Periode 2011-2015). Skripsi.

Rudiansyah Afif. (2014). Pengaruh Inflasi, Bi Rate, PDB Dan Nilai Tukar Rupiah Terhadap Simpanan Mudharabah Pada Bank Syariah Di Indonesia. Jurnal Ilmu Manajemen, 2(2), 306-317.

Ruslizar, \& Rahmawaty. (2016). Pengaruh Tingkat Bagi Hasil Deposito Mudharabah, Financing To Deposit Ratio, Dan Suku Bunga Deposito Terhadap Pertumbuhan Deposito Mudharabah Pada Bank Umum Syariah Di Indonesia. Jurnal Ilmiah Mahasiswa Ekonomi Akuntansi (JIMEKA), 1(2), 84-90.

Said, M., \& Ali, H. (2016). An analysis on the factors affecting profitability level of Sharia banking in Indonesia. Banks and Bank Systems, 11(3), 28-36. https://doi.org/10.21511/bbs.11(3).2016.03

Sayid, O., Musse, H., \& Echchabi, A. (2014). Factors Determining Islamic Banks' Deposits in Qatar: An Empirical Study. International Journal of Economic Practices and Theories, 4(6), 987-994.

Tersedia online : http://jurnal.stesislamicvillage.ac.id/index.php/JURNAL 
Sholikha, A. F. (2018). Pengaruh Tingkat Suku Bunga, Tingkat Bagi Hasil, Likuiditas, Inflasi, Ukuran Bank, dan Pertumbuhan Produk Domestik Bruto terhadap Deposito Mudharabah Bank Umum Syariah di Indonesia. El-Jizya: Jurnal Ekonomi Islam, 6(1), 1-22. https://doi.org/10.24090/ej.v6i1.2045

Sugiyono. (2010). Metode Penelitian Pendidikan Pendekatan Kuantitatif, kualitatif, dan R\&D. Bandung: Alfabeta.

Sugiyono. (2012). Metode Penelitian Bisnis (Cetakan Ke). Bandung: Alfabeta. Sukirno, S. (2015). Makroekonomi Teori Pengantar. Jakarta: PT Raja Grafindo Persada.

Sunyoto, D. (2013). Metodologi Penelitian Akuntansi. Bandung: PT Refika Aditama Anggota Ikapi.

Surya, F., Ananto, R. P., \& Rissi, D. M. (2016). Pengaruh Kualitas Audit Terhadap Hubungan Pengungkapan Other Comprehensive Income dengan Manajemen Laba Pada Perusahaan yang Terdaftar di Bursa Efek Indonesia. Jurnal Akuntansi Dan $\quad$ Manajemen, $\quad$ 13(2), 1-16. https://doi.org/https://doi.org/10.30630/jakmenpnp.13.2.131

Sutan, R. (2014). Perbankan Syariah. Jakarta: Kencana Prenadamedia Group. Tabrizi, A. (2014). Analisis Pengaruh Variabel Makro Terhadap Non Performing

Financing Bank Umum Syariah di Indonesia. Skripsi. UIN Jakarta. Universitas Islam Negeri Syarif Hidayatullah Jakarta.

Trisnadi. (2015). Pengaruh Financing to Deposit Ratiodan Dana Pihak Ketiga Terhadap Pembiayaan Mudharabah. Universitas Komputer Indonesia.

Uhar, S. (2014). Metode Penelitian Kuantitatif dan Tindakan. Bandung: Refika A. Umam, K. (2009). Trend pembentukan Bank Umum Syari'ah Pasca UndangUndang

Nomor 21 Tahun 2008 (Konsep, Regulasi, dan Implementasi). Yogyakarta: BPFE Yogayakrta.

Winarno, W. W. (2011). Analisis Ekonometrika dan Statistika dengan EVIEWS.

Yogyakarta: UPP STIM YKPN.

Zakaria. (2009). Dasar-dasar Manajemen Bank Syariah. Jakarta: Kencana Prenadamedia Group. 